\title{
Glass Waste Forms for Oak Ridge Tank Wastes: Fiscal Year 1997 Report for Task Plan SR-16WT-31, Task A
}

by

M. K. Andrews

Westinghouse Savannah River Company

Savannah River Site

RECORDS ADMINISTRATION

Aiken, South Carolina 29808

J. R. Harbour

T. B. Edwards

P. J. Workman

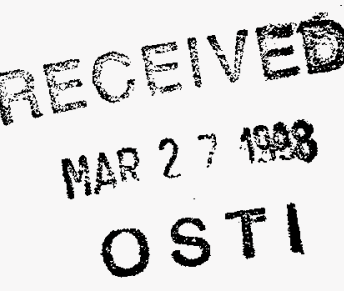

This paper was prepared in connection with work done under the above contract number with the U.S. Department of Energy. By acceptance of this paper, the publisher and/or recipient acknowledges the U. S. Government's right to retain a nonexclusive, royalty-free license in and to any copyright covering this paper, along with the right to reproduce and to authorize others to reproduce all or part of the copyrighted paper. 


\section{DISCLAIMER}

This report was prepared as an account of work sponsored by an agency of the United States Government. Neither the United States Government nor any agency thereof, nor any of their employees, makes any warranty, express or implied, or assumes any legal liability or responsibility for the accuracy, completeness, or usefulness of any information, apparatus, product, or process disclosed, or represents that its use would not infringe privately owned rights. Reference herein to any specific commercial product, process, or service by trade name, trademark, manufacturer, or otherwise does not necessarily constitute or imply its endorsement, recommendation, or favoring by the United States Government or any agency thereof. The views and opinions of authors expressed herein do not necessarily state or reflect those of the United States Government or any agency thereof.

This report has been reproduced directly from the best available copy.

Available to DOE and DOE contractors from the Office of Scientific and Technical Information, P. O. Box 62, Oak Ridge, TN 37831; prices available from (423) 576-8401.

Available to the public from the National Technical Information Service, U. S. Department of Commerce, 5285 Port Royal Road, Springfield, VA 22161. 


\section{DISCLAIMER}

Portions of this document may be illegible electronic image products. Images are produced from the best available original document. 


\section{WESTINGHOUSE SAVANNAH RIVER COMPANY SAVANNAH RIVER TECHNOLOGY CENTER}

WSRC-TR-97-00391

October 1,1997

\author{
GLASS WASTE FORMS FOR OAK RIDGE TANK WASTES: \\ FISCAL YEAR 1997 REPORT FOR TASK PLAN SR-16WT-31, TASK A (U)
}

\section{Introduction and Summary}

Through the Tanks Focus Area, the Office of Science and Technology has funded the Savannah River Technology Center (SRTC) and the Oak Ridge National Laboratory (ORNL) to develop formulations which can incorporate sludges from Oak Ridge (OR) Tank Farms into an immobilized waste form. SRTC has been developing a glass waste form, while ORNL has been developing a grout waste form for the tank farms sludges. The four tank farms included in this task are:

Melton Valley Storage Tanks (MVST)

Bethel Valley Evaporator Service Tanks (BVEST) .

Gunite and Associated Tanks (GAAT)

Old Hydrofracture Tanks (OHF)

The first element of the SRTC task for FY97 was to develop a glass formulation to immobilize a blended sludge from the MVST and the BVEST. ORNL had previously developed a soda-limesilicate (SLS) glass for the MVST sludge. SRTC has reproduced this work and expanded on it for the blended MVST/BVEST sludge. SRTC also performed a durability test on the resultant glasses. The normalized sodium and silicon leachate concentrations for the soda lime silica glasses readily met the Environmental Assessment glass (a borosilicate glass) benchmark limits for these two elements. Additional efforts at the SRTC included the verification of the glass formulation prior to the ORNL radioactive demonstration and technical consultations during the radioactive demonstration. However, the major emphasis for SRTC in FY97 was on the second element of this task, the overall blended average of the tank farms.

The second element focused on developing a glass formulation which would immobilize a sludge with a composition obtained from averaging the contents of all four tank farms (composite composition). Although blending the contents of all four tank farms is not feasible, this average composition provides a basis from which to develop a glass formulation. Once a frit formulation was developed which produced a durable glass waste form at relatively high waste loadings, then a statistically designed approach was implemented to determine the size of the sludge compositional window which could be adequately immobilized by the frit formulation.

This report summarizes the SRTC results of Task A of Task Plan SR-16WT-31 for FY97. 


\section{Experimental Details}

Using ORNL information on the characterization of the tank waste sludges, SRTC has been performing extensive bench-scale vitrification studies using simulants. Several glass systems have been tested to ensure the optimum glass composition is determined. This optimum composition will balance waste loading, melt temperature, waste form performance and disposal requirements. By optimizing the glass composition, a cost savings can be realized during vitrification of the waste. The preferred glass formulation will be selected from the bench-scale studies and recommended to ORNL for further testing with samples of actual OR waste tank sludges.

Studies were performed using simulant sludges that contained depleted uranium dioxide and reagent grade chemicals. The sludge simulant and appropriate glass-forming chemicals (or frit) were combined and placed in high-purity alumina crucibles. The samples were vitrified at $1100^{\circ} \mathrm{C}$ to $1300^{\circ} \mathrm{C}$ for four hours. The crucibles were then removed from the furnace and allowed to air cool to room temperature. The glass was broken out of the crucible and ground for analysis. Some glass samples were removed from the furnace after four hours and then poured into stainless steel pans. This provided an estimate of the viscosity of the glass.

The glass samples were analyzed to determine the chemical composition. Each sample was dissolved by two separate dissolution methods according to approved procedures. The dissolutions were analyzed by Atomic Absorption (AA) spectrometry and Inductively Coupled Plasma Emission Spectroscopy (ICP-ES). Glasses were also submitted for X-Ray Diffraction (XRD) to determine the crystalline content.

The glass durability was measured using the Product Consistency Test (PCT). The PCT is a crushed glass leach test that measures the releases of several elements from the glass. The test is performed in $90^{\circ} \mathrm{C}$ deionized water for seven days. The PCT creates leaching conditions which are more aggressive than those for the Toxicity Characteristic Leaching Procedure (TCLP) to provide information about glass durability under accelerated (worst case) leaching conditions. In addition, the PCT is a better indicator of the glass durability because it is a glass-dominated rather than a solution-dominated durability test. The results of the PCT test for each glass were compared to the Environmental Assessment (EA) glass to determine acceptability. The acceptance criteria for high-level waste glasses states that the glass produced must be more durable than the EA glass. Since there is currently no durability criteria for low-level waste, the EA glass benchmark values will be used.

\section{MVST/BVEST}

A report was written by ORNL describing the results of their glass formulation efforts for the MVST sludges. ${ }^{1}$ One formulation that ORNL tested contained approximately $14 \mathrm{wt} \% \mathrm{CaCO}_{3}$, $41 \mathrm{wt} \%$ dried ORNL MVST surrogate waste, and $45 \mathrm{wt} \% \mathrm{SiO}_{2}$ in the feed mix. This was the formulation used for confirmatory testing at the SRTC. Since the BVEST sludge composition is similar to the MVST sludge, the compositions were statistically averaged. A comparison of the compositions is provided in Table 1. A surrogate based on the MVST/BVEST sludge composition was developed at the SRTC and used for the confirmatory testing of the ORNL formulation. 
Table 1 - Comparison of the Major Components of the MVST, BVEST and Blended MVST/BVEST Sludges

\begin{tabular}{|c|c|c|c|}
\hline Species & $\begin{array}{c}\text { MVST } \\
\text { wt \% }\end{array}$ & $\begin{array}{c}\text { BVEST } \\
\text { wt } \%\end{array}$ & $\begin{array}{c}\text { MVST/BVEST } \\
\text { wt\% }\end{array}$ \\
\hline \hline $\mathrm{Al}$ & 1.4 & 0.6 & 1.2 \\
\hline $\mathrm{Ca}$ & 11.9 & 18.5 & 13.4 \\
\hline $\mathrm{Cl}$ & 0.7 & 0.7 & 0.7 \\
\hline $\mathrm{Fe}$ & 0.5 & 0.8 & 0.6 \\
\hline $\mathrm{K}$ & 3.1 & 4.0 & 3.3 \\
\hline $\mathrm{Mg}$ & 2.2 & 3.7 & 2.5 \\
\hline $\mathrm{Na}$ & 16.8 & 16.0 & 16.7 \\
\hline $\mathrm{NO} 3$ & 55.3 & 34.4 & 50.6 \\
\hline $\mathrm{P}$ & 0.5 & 3.1 & 1.1 \\
\hline $\mathrm{Si}$ & 1.6 & 0.5 & 1.3 \\
\hline $\mathrm{SO} 4$ & 0.4 & 1.3 & 0.6 \\
\hline $\mathrm{Th}$ & 1.5 & 4.4 & 2.2 \\
\hline $\mathrm{U}$ & 2.5 & 9.0 & 4.0 \\
\hline
\end{tabular}

In addition to testing the ORNL formulation, several other formulations (both borosilicate and soda-lime-silicate glasses) were developed by the SRTC. The borosilicate glasses were durable but due to phase separation concerns related to the high calcium content in the MVST/BVEST sludges, it was decided to continue only with soda-lime-silicate glasses. The chemical compositions of three different glass formulations with various sludge waste loadings (40,45 and $50 \mathrm{wt} \%$ ) are provided in Table 2. The column for the $40 \mathrm{wt} \%$ formulation is the ORNL developed formulation while the other two formulations were developed by the SRTC.

Table 2 - Major Chemical Compositions (in weight\% oxides) of Soda-Lime-Silica Glass using MVST/BVEST Surrogate

\begin{tabular}{|c|c|c|c|}
\hline Oxide & $\mathbf{4 0}$ wt \% & $\mathbf{4 5} \mathbf{w t} \%$ & $\mathbf{5 0}$ wt \% \\
\hline \hline $\mathrm{Al}_{2} \mathrm{O}_{3}$ & 3.98 & 9.53 & 3.87 \\
\hline $\mathrm{CaO}$ & 13.08 & 16.98 & 12.07 \\
\hline $\mathrm{Cr}_{2} \mathrm{O}_{3}$ & 0.01 & 0.18 & 0.20 \\
\hline $\mathrm{Fe}_{2} \mathrm{O}_{3}$ & 0.26 & 0.97 & 1.04 \\
\hline $\mathrm{K}_{2} \mathrm{O}$ & 1.57 & 1.61 & 0.33 \\
\hline $\mathrm{MgO}$ & 1.25 & 1.64 & 1.72 \\
\hline $\mathrm{Na}_{2} \mathrm{O}$ & 8.78 & 9.55 & 19.65 \\
\hline $\mathrm{SiO}_{2}$ & 51.07 & 47.23 & 57.26 \\
\hline $\mathrm{ThO}_{2}$ & 0.19 & 0.23 & 0.23 \\
\hline $\mathrm{UO}_{3}$ & 3.58 & 3.70 & 3.73 \\
\hline
\end{tabular}

The PCT was performed on all of the glass samples. Samples were run in triplicate and each 7 day test included the appropriate blanks and standards. The results of the standards and blanks indicated that the tests were acceptable. The average PCT releases for several elements were 
measured. These values were used along with the composition of the glass to calculate the average normalized release for silicon and sodium. The leachate $\mathrm{pH}$ was measured as part of the PCT protocol and provides a secondary indication of glass durability.

The normalized elemental releases reported in Table 3 indicate that the glasses made with surrogate MVST/BVEST waste met the HLW acceptance criteria, which states that the glass produced must be at least two standard deviations better than the Environmental Assessment (EA) glass.

Table 3 - Normalized PCT Results (in $\mathrm{g} / \mathrm{L}$ ) and Standard Deviations for Soda-Lime-Silica Glass using MVST/BVEST Surrogate

\begin{tabular}{|c|c|c|c|}
\hline Sample & Si & Na & pH \\
\hline \hline $40 \mathrm{wt} \%$ & $0.11 \pm 0.3$ & $6.86 \pm 0.2$ & 10.8 \\
\hline $45 \mathrm{wt} \%$ & $0.08 \pm 0.2$ & $0.61 \pm 0.6$ & 10.8 \\
\hline $50 \mathrm{wt} \%$ & $0.13 \pm 0.1$ & $6.34 \pm 0.7$ & 10.4 \\
\hline & & & \\
\hline EA & 3.9 & 13.3 & 11.9 \\
\hline
\end{tabular}

\section{Tank W-25}

The radioactive demonstrations at ORNL to confirm the nonradioactive glass and grout formulations were performed using sludge from MVST Tank W-25. Since this sludge differed in composition from the average MVST/BVEST sludge composition, additional testing using a surrogate Tank W-25 sludge was performed. The composition of the Tank W-25 sludge is included in Table 4 along with the average MVST/BVEST from Table 1. Four glass formulations were tested using the Tank W-25 surrogate, including the ORNL formulation that was developed for the average MVST sludge composition.

Table 4 - Comparison of the Major Components of the MVST Tank W-25 and the MVST/BVEST Compositions

\begin{tabular}{|c|c|c|}
\hline Species & $\begin{array}{c}\text { Tank W-25 } \\
\text { wt \% }\end{array}$ & $\begin{array}{c}\text { MVST/BVEST } \\
\text { wt\% }\end{array}$ \\
\hline $\mathrm{Al}$ & 3.6 & 1.2 \\
\hline $\mathrm{Ca}$ & 13.4 & 13.4 \\
\hline $\mathrm{Cl}$ & 0.5 & 0.7 \\
\hline $\mathrm{Fe}$ & 1.2 & 0.6 \\
\hline $\mathrm{K}$ & 2.0 & 3.3 \\
\hline $\mathrm{Mg}$ & 1.9 & 2.5 \\
\hline $\mathrm{Na}$ & 15.4 & 16.7 \\
\hline $\mathrm{NO}$ & 25.0 & 50.6 \\
\hline $\mathrm{P}$ & 1.3 & 1.1 \\
\hline $\mathrm{Si}$ & 2.1 & 1.3 \\
\hline $\mathrm{SO}_{4}$ & 1.0 & 0.6 \\
\hline $\mathrm{Th}$ & 8.0 & 2.2 \\
\hline $\mathrm{U}$ & 3.9 & 4.0 \\
\hline
\end{tabular}


Two of the tested formulations produced a homogeneous glass waste form that had a reasonable viscosity. These two glasses were subjected to the PCT to assess the durability. The results for the selected formulation was approximately $0.1 \mathrm{~g} / \mathrm{L}$ for silicon and approximately $0.4 \mathrm{~g} / \mathrm{L}$ for sodium. These results are significantly more durable than the EA glass (see Table 3 for the EA glass PCT results).

Based on the results, a mixture of $14.2 \mathrm{~g}$ of $\mathrm{SiO}_{2}, 8.12 \mathrm{~g}$ of $\mathrm{CaCO}_{3}$, and $25.0 \mathrm{~g}$ of dried Tank W25 sludge was recommended for the radioactive demonstration at ORNL. This should produce approximately $30 \mathrm{~g}$ of glass with a density of $2.87 \mathrm{~g} / \mathrm{cc}$. The recommended melt temperature was $1300^{\circ} \mathrm{C}$ for this glass formulation.

\section{Composite}

This portion of the task focused on developing a glass formulation which would immobilize a sludge composition obtained from the overall blended average of the four tank farms (composite composition). The goal of the work was to develop a glass frit formulation which would incorporate the composite sludge waste to produce an acceptable glass and then to determine the robustness of the developed frit (i.e., the sensitivity of the frit formulation to variations in the chemical composition around the average sludge).

The chemical composition of the composite sludge was obtained by calculating a weighted average of the contents of the four tank farms. The amount of sludge and chemical composition of the sludge in each tank farm was estimated as follows:

MVST: The MVST tank farm consists of eight 50,000 gallon tanks (Building 7830) identified as W-24 through W-31. Two of the tanks, W-29 and W-30, have been modified to serve as feed tanks and consequently could not be sampled. These two tanks (W-29 and W-30) have been excluded from defining the average MVST chemical composition and the amount of sludge. The average MVST composition is presented in Table 1.

BVEST: The BVEST tank farm consists of five 50,000 gallon tanks identified as W-21, W-22, W-23, C-1, and C-2. Tanks C-1 and C-2 were not sampled and consequently their contents have not been included in the determination of blended average of the BVEST. The BVEST composition is provided in Table 1.

GAAT: The tanks included for defining the average chemical composition of the GAAT sludge waste along with the amount of sludge are W-3 through W-10. The average GAAT results are shown in Table 5.

OHF: The OHF tank farm consists of five tanks, all of which were included in the calculation of the average chemical composition and the amount of sludge for OHF. Table 5 presents the average OHF composition.

Composite: The overall composite average was obtained by weighted averaging of the 5 OHF, 8 GAAT, and 9 MVST/BVEST tanks. The resulting composition is also provided in Table 5. This data was received from Oak Ridge on December 12, 1996 and was the agreed upon basis for the definition of the overall composite composition. 
Table 5 - Comparison of the Major Components of the GAAT, OHF and Composite Sludges

\begin{tabular}{|c|c|c|c|}
\hline Species & $\begin{array}{c}\text { GAAT } \\
\text { wt\% }\end{array}$ & $\begin{array}{c}\text { OHF } \\
\text { wt\% }\end{array}$ & $\begin{array}{c}\text { Composite } \\
\text { wt \% }\end{array}$ \\
\hline \hline $\mathrm{Al}$ & 9.3 & 7.1 & 2.5 \\
\hline $\mathrm{Ca}$ & 7.2 & 14.4 & 12.2 \\
\hline $\mathrm{Cl}$ & 0.3 & 0.3 & 0.6 \\
\hline $\mathrm{Fe}$ & 5.4 & 2.6 & 1.3 \\
\hline $\mathrm{K}$ & 2.4 & 1.6 & 3.1 \\
\hline $\mathrm{Mg}$ & 1.7 & 1.4 & 2.3 \\
\hline $\mathrm{Na}$ & 19.0 & 4.8 & 16.2 \\
\hline $\mathrm{NO} 3$ & 8.1 & 2.7 & 41.6 \\
\hline $\mathrm{P}$ & 0.6 & 3.5 & 1.5 \\
\hline $\mathrm{Si}$ & 1.9 & 6.8 & 1.7 \\
\hline $\mathrm{SO} 4$ & 3.1 & 0.7 & 0.9 \\
\hline $\mathrm{Th}$ & 5.6 & 47.1 & 3.7 \\
\hline $\mathrm{U}$ & 30.9 & 5.0 & 9.6 \\
\hline
\end{tabular}

\section{Composite Sludge Surrogate}

In order to develop a glass frit formulation, a simulant of the composite sludge was required. Based on the composition shown in the last column of Table 5, a surrogate sludge was developed. A few minor components ( $\sim 0.8 \%$ of the total composite composition) were eliminated from the SRTC surrogate. These minor components were not expected to affect the glass properties. Table 6 shows the compounds used for the SRTC composite surrogate. Enough surrogate was batched to make several crucible melts.

Table 6 - Amounts of Compounds used for the SRTC Surrogate

\begin{tabular}{|c|c|}
\hline Compound & $\begin{array}{c}\text { Amount } \\
\text { (wt \%) }\end{array}$ \\
\hline $\mathrm{Al}_{2} \mathrm{O}_{3}$ & 3.54 \\
\hline $\mathrm{CaCO}_{3}$ & 11.26 \\
\hline $\mathrm{Ca}\left(\mathrm{OH}_{2}\right.$ & 8.33 \\
\hline $\mathrm{K}_{2} \mathrm{CrO}_{4}$ & 0.23 \\
\hline $\mathrm{Fe}_{2} \mathrm{O}_{3}$ & 1.39 \\
\hline $\mathrm{KNO}_{3}$ & 5.17 \\
\hline $\mathrm{MgO}$ & 2.81 \\
\hline $\mathrm{MnO}_{3}$ & 0.08 \\
\hline $\mathrm{Na}_{2} \mathrm{CO}$ & 0.98 \\
\hline $\mathrm{Na}_{2} \mathrm{HPO}_{4} \cdot 7 \mathrm{H}_{2} \mathrm{O}$ & 8.82 \\
\hline $\mathrm{PbO}$ & 0.15 \\
\hline
\end{tabular}

\begin{tabular}{|c|c|}
\hline Compound & $\begin{array}{c}\text { Amount } \\
\text { (wt\%) }\end{array}$ \\
\hline $\mathrm{SiO}_{2}$ & 2.72 \\
\hline $\mathrm{Sr}_{\left(\mathrm{NO}_{3}\right)_{2}}$ & 0.11 \\
\hline $\mathrm{ThO}_{2}$ & 3.08 \\
\hline $\mathrm{UO}_{2}\left(\mathrm{NO}_{3}\right)^{\circ} 6 \mathrm{H}_{2} \mathrm{O}$ & 14.89 \\
\hline $\mathrm{ZnO}$ & 0.12 \\
\hline $\mathrm{NaCl}$ & 0.75 \\
\hline $\mathrm{NaF}$ & 0.34 \\
\hline $\mathrm{NaNO}_{3}$ & 32.62 \\
\hline $\mathrm{NaNO}_{2}$ & 1.18 \\
\hline $\mathrm{K}_{2} \mathrm{HPO}_{4}$ & 0.40 \\
\hline $\mathrm{Na}_{2} \mathrm{SO}_{4}$ & 1.03 \\
\hline
\end{tabular}




\section{Glass Formulation Scoping Studies}

Preliminary crucible vitrification tests were performed to determine the type and amount of reagent-grade chemicals that would be required with the composite sludge to produce a durable glass with the appropriate liquidus and viscosity processing properties. A few borosilicate glasses were tested, but the main emphasis was on testing SLS glasses. Five successful SLS frit formulations are shown in Table 7. Each of these formulations was combined with the same amount of composite surrogate (see Table 6), and vitrified at $1300^{\circ} \mathrm{C}$ for four hours. The surrogate loading (not on an oxide basis) for the scoping tests was $40 \mathrm{wt} \%$ dried material.

Table 7 - SLS Frit Compositions during the Composite Scoping Studies

\begin{tabular}{|c|c|c|c|c|c|}
\hline Component & $\mathbf{1}$ & $\mathbf{2}$ & $\mathbf{3}$ & $\mathbf{4}$ & $\mathbf{5}$ \\
\hline $\mathrm{SiO}_{2}$ & 68 & 62 & 60 & 72 & 78 \\
\hline $\mathrm{Li}_{2} \mathrm{O}$ & 13 & 18 & 14 & 12 & 12 \\
\hline $\mathrm{CaO}$ & 8 & 9 & 7 & 12 & 10 \\
\hline $\mathrm{Na}_{2} \mathrm{O}$ & 4 & 8 & 4 & 4 & 0 \\
\hline $\mathrm{Fe}_{2} \mathrm{O}_{3}$ & 3 & 2 & 10 & 0 & 0 \\
\hline $\mathrm{Al}_{2} \mathrm{O}_{3}$ & 4 & 1 & 0 & 0 & 0 \\
\hline $\mathrm{K}_{2} \mathrm{O}$ & 0 & 0 & 5 & 0 & 0 \\
\hline
\end{tabular}

The five glasses resulting from the frit compositions shown in Table 7 were each subjected to the PCT. The normalized releases for silicon and sodium are shown in Table 8, along with the corresponding average $\mathrm{pH}$ of the leachate. These five compositions were used as the basis for the statistical optimization of the frit formulation.

Table 8 - SLS PCT Results (in $\mathrm{g} / \mathrm{L}$ ) for the Composite Scoping Studies

\begin{tabular}{|c|c|c|c|}
\hline Sample & $\mathbf{S i}$ & $\mathbf{N a}$ & $\mathbf{p H}$ \\
\hline \hline 1 & 0.28 & 1.23 & 10.5 \\
\hline 2 & 1.43 & 10.80 & 11.1 \\
\hline 3 & 0.61 & 9.61 & 10.5 \\
\hline 4 & 0.14 & 0.83 & 11.1 \\
\hline 5 & 0.19 & 1.56 & 10.4 \\
\hline
\end{tabular}

\section{Optimization of Frit Formulation}

While maintaining the sludge composition constant, the components of the frit formulation were statistically varied to determine the optimal composition (i.e. a composition that would allow sufficient waste loadings, while still maintaining the appropriate liquidus, viscosity and durability properties). Using the composition of the surrogate sludge and the five SLS formulations in Table 7, a final glass composition was calculated for waste loadings of 33 and $55 \mathrm{wt} \%$ sludge oxides. This led to 10 compositions. Using these 10 glass compositions, a high and a low value for each frit component was determined and is shown in Table 9. The values in Table 9 include the contributions from the sludge for each component. All sludge components that were not a 
frit component are included in the row titled "Others". Details on the statistical approach used for this study are provided in Appendix I.

Table 9 - Glass Composition Ranges of Components for the Frit Optimization Study (in weight fraction)

\begin{tabular}{|c|c|c|}
\hline Component & Low Value & High Value \\
\hline $\mathrm{Al}_{2} \mathrm{O}_{3}$ & 0.0161 & 0.0520 \\
\hline $\mathrm{CaO}$ & 0.1051 & 0.1752 \\
\hline $\mathrm{Fe}_{2} \mathrm{O}_{3}$ & 0.0080 & 0.0733 \\
\hline $\mathrm{K}_{2} \mathrm{O}$ & 0.0145 & 0.0450 \\
\hline $\mathrm{Li}_{2} \mathrm{O}$ & 0.0540 & 0.1206 \\
\hline $\mathrm{Na}_{2} \mathrm{O}$ & 0.0871 & 0.2474 \\
\hline $\mathrm{SiO}_{2}$ & 0.2915 & 0.5383 \\
\hline Others & 0.0874 & 0.1859 \\
\hline
\end{tabular}

Using the range in Table 9, the extreme vertices of the multi-dimensional space of glass composition were computed. Sixteen glass compositions that would provide the most information regarding possible linear effects among the components were determined, along with the centroid of this multi-dimensional space. The selected glass compositions were converted to frit compositions, which are provided in Table 10, along with the waste loading used. Sample number 17 was the determined centroid for the region and was used to help critique the performance of the linear model. Appendix I describes the method used to select the glass compositions.

Table 10 - Frit Compositions (in weight \%) used for the Frit Optimization Study

\begin{tabular}{|c|c|c|c|c|c|c|c|c|}
\hline ID & Loading & $\mathrm{Al}_{2} \mathbf{O}_{3}$ & $\mathbf{C a O}$ & $\mathrm{Fe}_{2} \mathbf{O}_{3}$ & $\mathbf{K}_{2} \mathbf{O}$ & $\mathbf{L i}_{2} \mathbf{O}$ & $\mathrm{Na}_{2} \mathbf{O}$ & $\mathrm{SiO}_{2}$ \\
\hline 1 & 33.01 & 5.36 & 17.47 & 10.00 & 0.45 & 8.06 & 16.38 & 42.29 \\
\hline 2 & 33.01 & 5.36 & 17.47 & 0.25 & 5.00 & 8.06 & 16.38 & 47.48 \\
\hline 3 & 33.01 & 5.36 & 7.00 & 10.00 & 0.45 & 18.00 & 16.38 & 42.81 \\
\hline 4 & 33.01 & 5.36 & 7.00 & 0.25 & 5.00 & 18.00 & 16.38 & 48.01 \\
\hline 5 & 33.01 & 5.36 & 7.00 & 0.25 & 0.45 & 8.06 & 0.45 & 78.43 \\
\hline 6 & 33.01 & 0.00 & 17.47 & 0.25 & 5.00 & 18.00 & 16.38 & 42.90 \\
\hline 7 & 33.01 & 0.00 & 7.00 & 10.00 & 5.00 & 8.06 & 16.38 & 53.56 \\
\hline 8 & 33.01 & 0.00 & 7.00 & 10.00 & 0.45 & 8.06 & 16.38 & 58.11 \\
\hline 9 & 33.01 & 0.00 & 7.00 & 0.25 & 5.00 & 8.06 & 1.26 & 78.43 \\
\hline 10 & 33.01 & 0.00 & 7.00 & 0.25 & 0.45 & 18.00 & 16.38 & 57.92 \\
\hline 11 & 33.01 & 0.00 & 17.47 & 10.00 & 0.45 & 18.00 & 2.48 & 51.61 \\
\hline 12 & 33.01 & 0.00 & 17.47 & 10.00 & 5.00 & 18.00 & 0.20 & 49.33 \\
\hline 13 & 33.01 & 5.36 & 7.00 & 10.00 & 5.00 & 18.00 & 2.75 & 51.89 \\
\hline 14 & 56.52 & 1.48 & 1.26 & 14.37 & 5.83 & 12.42 & 2.69 & 61.96 \\
\hline 15 & 57.82 & 1.55 & 0.76 & 8.16 & 2.44 & 21.86 & 1.48 & 63.75 \\
\hline 16 & 55.01 & 0.00 & 12.00 & 0.00 & 0.00 & 12.00 & 3.99 & 72.01 \\
\hline 17 & 34.71 & 2.97 & 12.48 & 5.68 & 2.83 & 13.72 & 11.81 & 50.50 \\
\hline
\end{tabular}


Each of the frit compositions shown in Table 10 was batched and then mixed with the appropriate amount of the sludge surrogate. The centroid (ID 17) was the first glass vitrified and then all of the others were melted in a random order. After four hours at $1300^{\circ} \mathrm{C}$, the samples were removed from the furnace and poured into a stainless steel pan. The relative viscosity of each sample was then determined and given a numerical rating between 1 and 3, with intervals of 0.5 . A viscosity rating of 2.5 or 3.0 was deemed acceptable. While a rating of 2.0 was marginal and could prove to be acceptable, depending on the melter system, it was decided to be conservative by considering it unacceptable. Low values were given for a sample that was either too viscous or too fluid.

In addition to a viscosity rating, a liquidus rating was given to each sample based on visual observation for crystals or other non-glassy phases. The numerical rating ranged from 1 to 7 , with a minimum of 5 being considered acceptable. Table 11 summarizes the ratings for each of the 17 tested glasses.

Table 11 - Ratings for the Glasses in the Frit Optimization Study

\begin{tabular}{|c|c|c|}
\hline ID & $\begin{array}{c}\text { Liquidus } \\
\text { rating }\end{array}$ & $\begin{array}{c}\text { Viscosity } \\
\text { rating }\end{array}$ \\
\hline 1 & 4 & 2.0 \\
\hline 2 & 2 & 3.0 \\
\hline 3 & 1 & 3.0 \\
\hline 4 & 2 & 3.0 \\
\hline 5 & 7 & 3.0 \\
\hline 6 & 1 & 3.0 \\
\hline 7 & 6 & 3.0 \\
\hline 8 & 6 & 3.0 \\
\hline 9 & 7 & 3.0 \\
\hline 10 & 3 & 2.0 \\
\hline 11 & 6 & 3.0 \\
\hline 12 & 5 & 3.0 \\
\hline 13 & 5 & 3.0 \\
\hline 14 & 3 & 3.0 \\
\hline 15 & 4 & 3.0 \\
\hline 16 & 3 & 3.0 \\
\hline 17 & 4 & 3.0 \\
\hline
\end{tabular}

The five highest rated glasses $(5,7,8,9$ and 11$)$ had waste loadings of 33.01 wt\% sludge oxides. Therefore, the sludge loading of each of these glasses was increased to $45 \mathrm{wt} \%$. The melting and pouring procedures were repeated and liquidus and viscosity ratings were given to the new glasses. The ratings for the five glasses with $45 \mathrm{wt} \%$ sludge oxide loadings are given in Table 12. 
Table 12 - Ratings for the 45 wt\% Sludge Oxide Glasses

\begin{tabular}{|c|c|c|}
\hline ID & $\begin{array}{c}\text { Liquidus } \\
\text { rating }\end{array}$ & $\begin{array}{c}\text { Viscosity } \\
\text { rating }\end{array}$ \\
\hline 5 & 7 & 3.0 \\
\hline 7 & 3 & 3.0 \\
\hline 8 & 4 & 3.0 \\
\hline 9 & 7 & 3.0 \\
\hline 11 & 5 & 3.0 \\
\hline
\end{tabular}

The ratings for the 22 glasses (Tables 11 and 12) indicated that the glasses in the tested region generally had acceptable viscosities but liquidus was a concern. The results of the ratings were statistically evaluated to determine the factors affecting the properties. Based on the limited data from these samples, several components of the frit were determined to be statistically significant in contributing to the ratings. Three of these frit components $\left(\mathrm{SiO}_{2}, \mathrm{Fe}_{2} \mathrm{O}_{3}\right.$, and $\left.\mathrm{CaO}\right)$ were found to improve the liquidus property. Therefore, six new frit compositions, using only these three components were tested. The frit compositions tested are given in Table 13.

Table 13 - Frit Compositions for Liquidus Optimization

\begin{tabular}{|c|c|c|c|c|c|c|}
\hline Component & $\mathbf{1}$ & $\mathbf{2}$ & $\mathbf{3}$ & $\mathbf{4}$ & $\mathbf{5}$ & $\mathbf{6}$ \\
\hline $\mathrm{SiO}_{2}$ & 72 & 60 & 85 & 70 & 50 & 78 \\
\hline $\mathrm{CaO}$ & 8 & 2 & 12 & 19 & 25 & 8 \\
\hline $\mathrm{Fe}_{2} \mathrm{O}_{3}$ & 20 & 38 & 3 & 11 & 25 & 14 \\
\hline
\end{tabular}

The frit compositions listed in Table 13 were each combined with the appropriate amount of composite surrogate sludge to produce a glass with a waste loading of $45 \mathrm{wt} \%$ sludge oxides. After four hours of melting at $1300^{\circ} \mathrm{C}$, the crucibles were removed and the glass was poured into stainless steel pans. The glasses were each given viscosity and liquidus ratings. The results of the ratings are provided in Table 14.

Table 14 - Ratings for the Liquidus Optimization Glasses

\begin{tabular}{|c|c|c|}
\hline ID & $\begin{array}{c}\text { Liquidus } \\
\text { rating }\end{array}$ & $\begin{array}{c}\text { Viscosity } \\
\text { rating }\end{array}$ \\
\hline \hline 1 & 7 & 1.0 \\
\hline 2 & 7 & 3.0 \\
\hline 3 & 7 & 1.0 \\
\hline 4 & 7 & 2.0 \\
\hline 5 & 7 & 3.0 \\
\hline 6 & 7 & 1.0 \\
\hline
\end{tabular}


The results indicated that the region tested was completely acceptable for liquidus, but not totally acceptable for viscosity. These results were included in an expanded statistical evaluation of all of the results. As a part of the evaluation, a ternary diagram was plotted with $\mathrm{SiO}_{2}, \mathrm{Fe}_{2} \mathrm{O}_{3}$, and $\mathrm{CaO}$ on one axis, $\mathrm{Na}_{2} \mathrm{O}, \mathrm{Li}_{2} \mathrm{O}, \mathrm{K}_{2} \mathrm{O}$ and $\mathrm{Al}_{2} \mathrm{O}_{3}$ on another axis, and all other sludge component ("Others") on the third axis. This ternary is shown in Figure 1. A region of glasses with acceptable liquidus and viscosity ratings was beginning to be defined on this ternary diagram. Although an exact frit composition had not yet been determined, it was decided to begin varying the sludge composition while narrowing the composition of the frit.

\section{Variation in Sludge Composition}

At this stage of frit selection, a rather limited range of variation in sludge was established. The focus was on eight components in the sludge which generally make up greater than $90 \%$ of the sludge on an oxide basis. Lithium, which was included as a variable in the initial experiments, was not included in these experiments because it was a negative (or insignificant) factor on the liquidus and viscosity ratings and because it was not present in the sludge composition. The eight elements selected, along with the initial high and low values, are listed in Table 15. All components of the sludge that were not listed individually were grouped in the "Others" category. The statistical approach used for each phase of the sludge variation study was similar to the method detailed in Appendix I.

Table 15 - Initial Range of Sludge Components for the OR Sludge

\begin{tabular}{|c|c|c|}
\hline Component & Low & High \\
\hline $\mathrm{Al}_{2} \mathrm{O}_{3}$ & 0.005 & 0.050 \\
\hline $\mathrm{CaO}$ & 0.280 & 0.360 \\
\hline $\mathrm{Fe}_{2} \mathrm{O}_{3}$ & 0.004 & 0.014 \\
\hline $\mathrm{K}_{2} \mathrm{O}$ & 0.044 & 0.136 \\
\hline $\mathrm{Na}_{2} \mathrm{O}$ & 0.250 & 0.400 \\
\hline $\mathrm{MgO}^{\mathrm{SiO}}$ & 0.055 & 0.110 \\
\hline $\mathrm{U}_{3} \mathrm{O}_{8}$ & 0.010 & 0.090 \\
\hline $\mathrm{Others}$ & 0.040 & 0.130 \\
\hline
\end{tabular}

For Phase I of the sludge variation study, the frit components listed in Table 7 were also varied, and the waste loading was narrowed to $40 \pm 2 \mathrm{wt} \%$ sludge oxides. The extreme vertices of the final glass composition were computed from these ranges. Using the D-Optimal Design routine (as described in Appendix I), twelve of the extreme vertices glass compositions were selected for testing. The centroid of the region was also tested. In addition, twelve glass compositions within the multi-dimensional space were selected. The centroid and selected interior points assisted in the examination of the linear model. The glass compositions are shown in Table 16. The first sample listed is the centroid, the next twelve compositions are the extreme vertices and the last twelve glasses are the interior points. The interior points were selected from the set of vertices of the compositional region that was half-way between the extreme vertices and the centroid. 


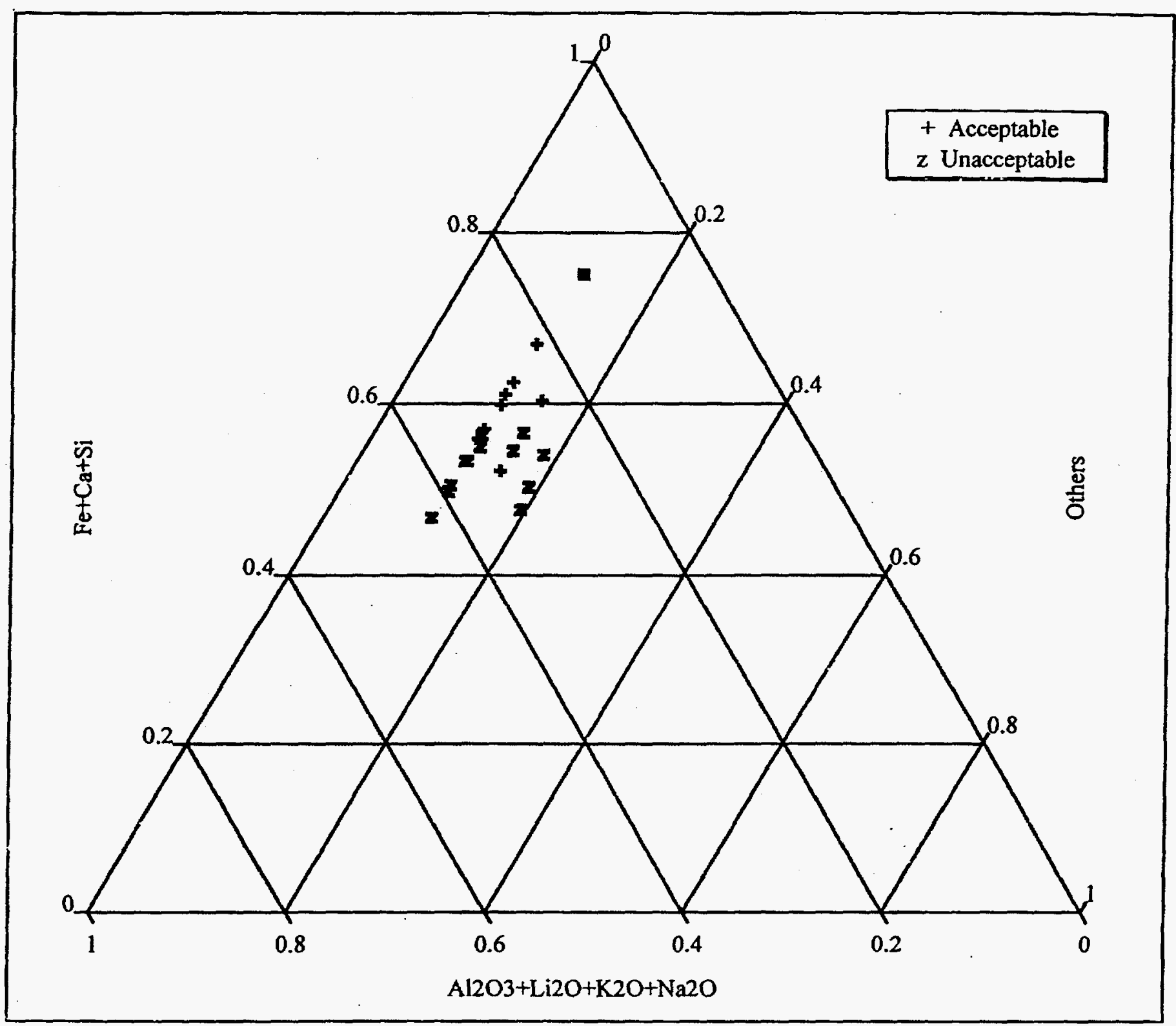

Figure 1 - Frit Optimization Ternary Diagram 
Table 16 - Glass Compositions Used during the Phase I Study (in weight \%)

\begin{tabular}{|c|c|c|c|c|c|c|c|c|c|}
\hline $\mathrm{ID}$ & $\mathrm{Al}_{2} \mathbf{O}_{3}$ & $\mathbf{C a O}$ & $\mathrm{Fe}_{2} \mathbf{O}_{3}$ & $\mathrm{~K}_{2} \mathbf{O}$ & $\mathrm{Na}_{2} \mathbf{O}$ & $\mathrm{MgO}$ & $\mathrm{SiO}_{2}$ & $\mathbf{U}_{3} \mathbf{O}_{8}$ & Others \\
\hline 1 & 1.16 & 20.93 & 12.71 & 3.68 & 13.09 & 3.35 & 38.26 & 3.48 & 3.34 \\
\hline 2 & 0.19 & 29.62 & 11.92 & 5.71 & 9.50 & 2.09 & 29.42 & 5.46 & 6.09 \\
\hline 3 & 0.19 & 29.62 & 5.97 & 1.67 & 16.80 & 4.62 & 29.58 & 5.46 & 6.09 \\
\hline 4 & 0.19 & 17.76 & 5.97 & 5.71 & 16.80 & 4.62 & 46.82 & 1.52 & 0.61 \\
\hline 5 & 0.19 & 28.57 & 19.13 & 1.67 & 16.80 & 2.09 & 29.42 & 1.52 & 0.61 \\
\hline 6 & 0.19 & 11.88 & 17.74 & 5.71 & 9.50 & 2.09 & 46.82 & 5.46 & 0.61 \\
\hline 7 & 0.19 & 11.88 & 19.13 & 1.67 & 9.50 & 4.62 & 45.40 & 1.52 & 6.09 \\
\hline 8 & 2.10 & 13.00 & 5.97 & 1.67 & 16.80 & 2.09 & 46.82 & 5.46 & 6.09 \\
\hline 9 & 2.10 & 17.14 & 19.13 & 5.71 & 16.80 & 2.09 & 29.42 & 1.52 & 6.09 \\
\hline 10 & 2.10 & 27.49 & 19.13 & 1.67 & 9.50 & 4.62 & 29.42 & 5.46 & 0.61 \\
\hline 11 & 2.10 & 29.62 & 6.07 & 1.67 & 9.50 & 2.09 & 46.82 & 1.52 & 0.61 \\
\hline 12 & 2.10 & 11.88 & 19.13 & 5.71 & 16.80 & 4.62 & 33.69 & 5.46 & 0.61 \\
\hline 13 & 2.10 & 29.62 & 5.97 & 5.71 & 9.50 & 4.62 & 34.87 & 1.52 & 6.09 \\
\hline 14 & 0.68 & 19.96 & 9.34 & 4.70 & 14.95 & 3.35 & 42.54 & 2.50 & 1.98 \\
\hline 15 & 0.68 & 24.29 & 9.34 & 2.68 & 11.30 & 2.72 & 42.54 & 4.47 & 1.98 \\
\hline 16 & 0.68 & 25.01 & 15.92 & 2.68 & 11.30 & 3.35 & 33.84 & 2.50 & 4.72 \\
\hline 17 & 0.68 & 16.41 & 15.92 & 4.70 & 14.95 & 2.72 & 35.43 & 4.47 & 4.72 \\
\hline 18 & 1.54 & 16.41 & 9.34 & 2.68 & 14.95 & 3.35 & 42.54 & 4.47 & 4.72 \\
\hline 19 & 1.63 & 25.28 & 12.45 & 2.68 & 14.95 & 2.72 & 33.84 & 4.47 & 1.98 \\
\hline 20 & 1.63 & 16.41 & 15.92 & 2.68 & 11.30 & 2.72 & 42.12 & 2.50 & 4.72 \\
\hline 21 & 1.63 & 16.41 & 15.92 & 4.70 & 11.30 & 3.35 & 40.24 & 4.47 & 1.98 \\
\hline 22 & 1.63 & 23.15 & 15.92 & 2.68 & 14.95 & 3.35 & 33.84 & 2.50 & 1.98 \\
\hline 23 & 1.63 & 23.29 & 9.34 & 4.70 & 11.30 & 2.72 & 42.54 & 2.50 & 1.98 \\
\hline 24 & 1.63 & 25.28 & 9.34 & 4.70 & 14.95 & 2.72 & 34.16 & 2.50 & 4.72 \\
\hline 25 & 1.63 & 25.28 & 10.71 & 4.70 & 11.30 & 3.35 & 33.84 & 4.47 & 4.72 \\
\hline
\end{tabular}

The glasses were batched and melted in a random order. After four hours at $1300^{\circ} \mathrm{C}$, the alumina crucibles were removed from the furnace and the glass was poured into stainless steel pans. The ratings for each of the glasses are provided in Table 17. 
Table 17 - Ratings for the Glasses in the Phase I Study

\begin{tabular}{|c|c|c|}
\hline ID & $\begin{array}{c}\text { Liquidus } \\
\text { rating }\end{array}$ & $\begin{array}{l}\text { Viscosity } \\
\text { rating }\end{array}$ \\
\hline 1 & 7 & 3.0 \\
\hline 2 & 5 & 3.0 \\
\hline 3 & 2 & 3.0 \\
\hline 4 & 7 & 3.0 \\
\hline 5 & 6 & 3.0 \\
\hline 6 & 7 & 3.0 \\
\hline 7 & 7 & 3.0 \\
\hline 8 & 7 & 3.0 \\
\hline 9 & 5 & 3.0 \\
\hline 10 & 6 & 3.0 \\
\hline 11 & 7 & 3.0 \\
\hline 12 & 5 & 3.0 \\
\hline 13 & 6 & 3.0 \\
\hline 14 & 7 & 3.0 \\
\hline 15 & 7 & 3.0 \\
\hline 16 & 7 & 3.0 \\
\hline 17 & 7 & 3.0 \\
\hline 18 & 7 & 3.0 \\
\hline 19 & 7 & 3.0 \\
\hline 20 & 7 & 3.0 \\
\hline 21 & 7 & 3.0 \\
\hline 22 & 7 & 3.0 \\
\hline 23 & 7 & 3.0 \\
\hline 24 & 7 & 3.0 \\
\hline 25 & 7 & 3.0 \\
\hline
\end{tabular}

With only one exception (sample \#3), all of the glasses were considered acceptable. The results for Phase I of the sludge variation study were statistically evaluated and were included with the results for the frit optimization study. Since there were more data points, a more detailed analysis could be performed. Three components of the frit $\left(\mathrm{SiO}_{2}, \mathrm{Fe}_{2} \mathrm{O}_{3}\right.$, and $\left.\mathrm{CaO}\right)$ continued to be the most significant positive factors in both the liquidus and viscosity ratings. Therefore, for Phase II of the sludge variation study, only these three components were used for the frit. The range of values used for these components is shown in Table 18. 
Table 18 - Frit Composition Ranges for Phase II of the Sludge Variation Study (in weight fraction)

\begin{tabular}{|c|c|c|}
\hline Component & Low Value & High Value \\
\hline $\mathrm{CaO}$ & 0.020 & 0.250 \\
\hline $\mathrm{Fe}_{2} \mathrm{O}_{3}$ & 0.100 & 0.300 \\
\hline $\mathrm{SiO}_{2}$ & 0.500 & 0.700 \\
\hline
\end{tabular}

For Phase II, the range for the sludge components was expanded. The range of sludge composition was extended to include a greater percentage of the overall tank wastes. Again, the same eight elements were considered and a range selected which included most of the variations within the BVEST and MVEST tanks, as well as the averages for the GAAT and OHF tanks. The extended range is provided in Table 19 in units of wt\% oxide.

Table 19 - Extended Range of Sludge Components (as Oxides) for the OR Sludge.

\begin{tabular}{|c|c|c|}
\hline Oxide & Low & High \\
\hline \hline $\mathrm{Al}_{2} \mathrm{O}_{3}$ & 0.003 & 0.155 \\
\hline $\mathrm{CaO}$ & 0.140 & 0.410 \\
\hline $\mathrm{Fe}_{2} \mathrm{O}_{3}$ & 0.002 & 0.025 \\
\hline $\mathrm{K}_{2} \mathrm{O}$ & 0.015 & 0.136 \\
\hline $\mathrm{Na}_{2} \mathrm{O}$ & 0.125 & 0.500 \\
\hline $\mathrm{MgO}$ & 0.015 & 0.110 \\
\hline $\mathrm{SiO}_{2}$ & 0.005 & 0.106 \\
\hline $\mathrm{U}_{3} \mathrm{O}_{8}$ & 0.020 & 0.320 \\
\hline $\mathrm{Others}$ & 0.008 & 0.218 \\
\hline
\end{tabular}

The expected glass compositions were calculated for all combinations of the ranges in Tables 18 and 19. These calculations again used waste loadings between 38 and 42 wt $\%$ sludge oxides. For each of the components, the low and the high values at the extreme vertices were determined. In addition, an internal region was calculated along with the centroid of the space. The low and the high values at the extreme vertices and at the internal points are shown in Table 20 for each of the components. The composition of the centroid is also provided.

Table 20 - Glass Composition Ranges for Phase II Study

\begin{tabular}{|c|c|c|c|c|c|}
\hline Component & $\begin{array}{c}\text { Extreme } \\
\text { Low }\end{array}$ & $\begin{array}{c}\text { Internal } \\
\text { Low }\end{array}$ & Centroid & $\begin{array}{c}\text { Internal } \\
\text { High }\end{array}$ & $\begin{array}{c}\text { Extreme } \\
\text { High }\end{array}$ \\
\hline \hline $\mathrm{Al} 2 \mathrm{O} 3$ & 0.0010 & 0.0152 & 0.0292 & 0.0472 & 0.0650 \\
\hline $\mathrm{CaO}$ & 0.1150 & 0.1375 & 0.1598 & 0.1950 & 0.2300 \\
\hline $\mathrm{Fe} 2 \mathrm{O} 3$ & 0.1280 & 0.1326 & 0.1367 & 0.1413 & 0.1460 \\
\hline $\mathrm{K} 2 \mathrm{O}$ & 0.0060 & 0.0174 & 0.0291 & 0.0431 & 0.0570 \\
\hline $\mathrm{Na} 2 \mathrm{O}$ & 0.0480 & 0.0728 & 0.0980 & 0.1540 & 0.2100 \\
\hline $\mathrm{MgO}$ & 0.0060 & 0.0152 & 0.0246 & 0.0352 & 0.0460 \\
\hline $\mathrm{SiO} 2$ & 0.3970 & 0.4114 & 0.4262 & 0.4440 & 0.4620 \\
\hline $\mathrm{U} 3 \mathrm{O} 8$ & 0.0080 & 0.0316 & 0.0556 & 0.0950 & 0.1340 \\
\hline Others & 0.0030 & 0.0219 & 0.0407 & 0.0661 & 0.0920 \\
\hline
\end{tabular}


Of the 465 extreme vertices that were determined from the region defined by the values in Table 20, twelve glass compositions were selected using the D-Optimal Design detailed in Appendix I. These compositions were chosen because they were determined to provide the most information about the effects on the properties. Twelve additional glasses were selected from the vertices of the interior region. After melting and pouring, liquidus and viscosity ratings were given to all 24 glasses. These ratings are shown in Table 21 .

Table 21 - Ratings for the Glasses in the Phase II Study

\begin{tabular}{|c|c|c|}
\hline ID & $\begin{array}{c}\text { Liquidus } \\
\text { rating }\end{array}$ & $\begin{array}{c}\text { Viscosity } \\
\text { rating }\end{array}$ \\
\hline 1 & 7 & 2.0 \\
\hline 2 & 7 & 3.0 \\
\hline 3 & 7 & 3.0 \\
\hline 4 & 7 & 3.0 \\
\hline 5 & 7 & 3.0 \\
\hline 6 & 7 & 3.0 \\
\hline 7 & 7 & 3.0 \\
\hline 8 & 7 & 3.0 \\
\hline 9 & 7 & 1.5 \\
\hline 10 & 5 & 1.0 \\
\hline 11 & 7 & 3.0 \\
\hline 12 & 7 & 3.0 \\
\hline 13 & 7 & 2.0 \\
\hline 14 & 7 & 3.0 \\
\hline 15 & 7 & 3.0 \\
\hline 16 & 7 & 3.0 \\
\hline 17 & 7 & 2.5 \\
\hline 18 & 7 & 3.0 \\
\hline 19 & 7 & 3.0 \\
\hline 20 & 7 & 3.0 \\
\hline 21 & 7 & 2.5 \\
\hline 22 & 7 & 2.0 \\
\hline 23 & 7 & 1.5 \\
\hline 24 & 7 & 3.0 \\
\hline & & \\
\hline
\end{tabular}

Prior to vitrification, the available data were used to predict the liquidus rating for each of the 24 glasses. A viscosity rating was not predicted. Only one glass (\#2) was predicted to have a liquidus rating below 5 . Its predicted rating was 4.5 , but the experimental rating was 7 . The results from these 24 glasses were incorporated into the models to assist in future predictions.

All of the results were plotted on another ternary diagram, with $\mathrm{SiO}_{2}$ on one axis, $\mathrm{Fe}_{2} \mathrm{O}_{3}$ and $\mathrm{CaO}$ on the second axis and all other components on the third axis. On this ternary diagram, shown in Figure 2, a region of the compositional space was beginning to form where acceptable liquidus and viscosity ratings were expected. This region indicated that additional $\mathrm{Fe}_{2} \mathrm{O}_{3}$ and 


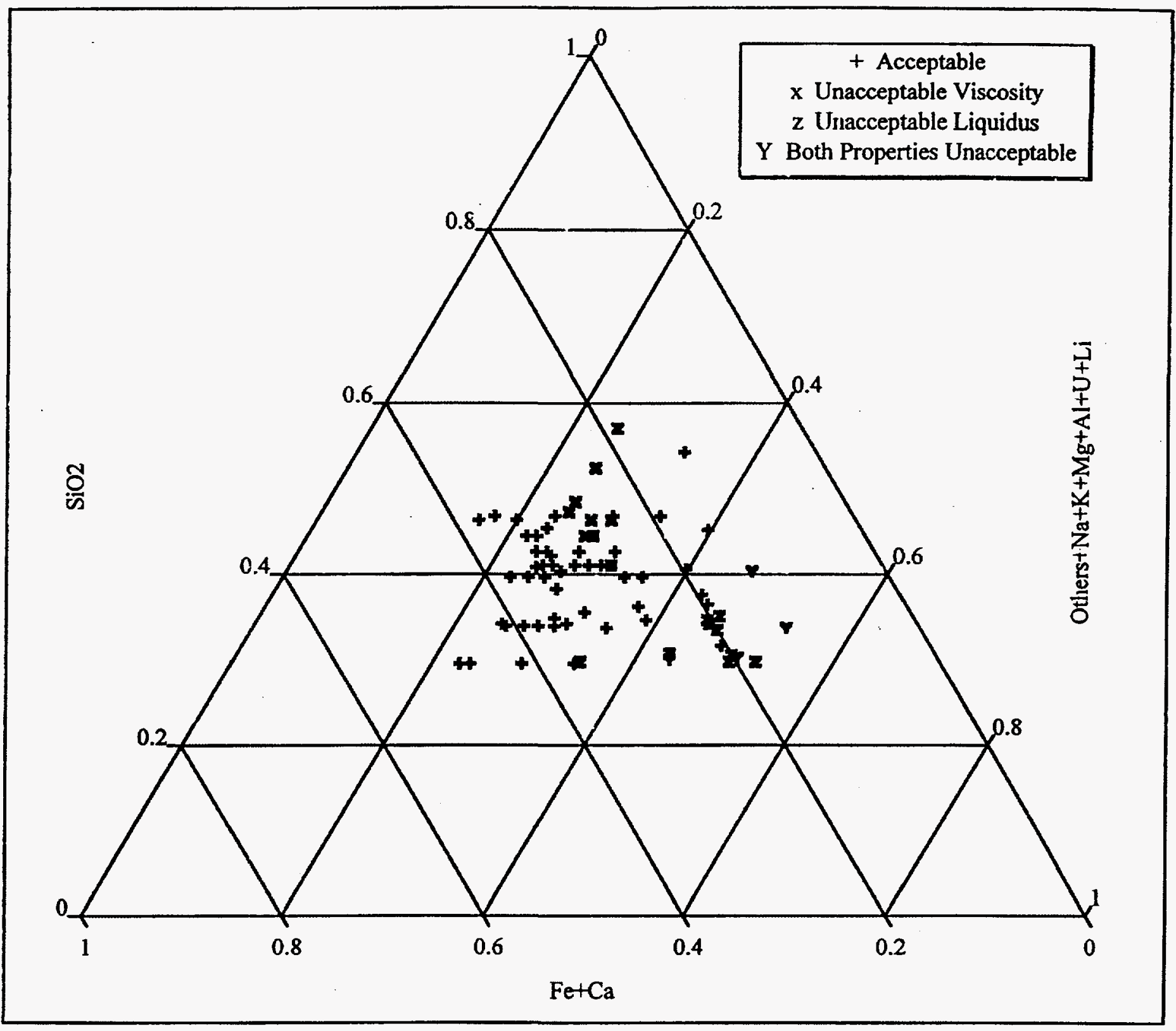

Figure 2 - Phase II Ternary Diagram 
$\mathrm{CaO}$ were desired. Therefore, for Phase III of this study, the frit was adjusted to a fixed composition and the waste loading was increased to $45 \pm 2 \mathrm{wt} \%$ sludge oxides. This would force the glass compositions into the acceptable regions. The results of Phase III testing will be reported in FY98. Additional testing expected to be completed in FY98 includes an examination of the minor components of the sludge. While the minor components were included and varied in all of the FY97 experiments, the relative amounts of the minor components were held constant. It will be necessary to determine the influence these minor components have on the glass properties.

\section{Waste Compliance Activities}

Since reasonable waste loadings would result in the glass being classified as transuranic (TRU), disposal of the vitrified waste form at the Waste Isolation Pilot Plant (WIPP) would be an option. Compliance with the WIPP Waste Acceptance Criteria (WAC) has been demonstrated and is detailed in a report which is attached as Appendix II.

\section{Preliminary Estimate of the Amount of Glass Produced}

There is uncertainty in the total amount of sludge present in the four OR Tank Farms. For the preliminary calculation of the total amount of glass that would be produced if all of the sludge was vitrified, it is assumed that approximately one million kilograms of sludge slurry is currently in the OR tanks. During vitrification, the dry sludge will become integrated into the glass matrix as oxides of the elements. The calcine factor is assumed to be 1.5 for this calculation. The final assumption is based on maintaining a waste loading of $40 \mathrm{wt} \%$ sludge oxides.

Using these assumptions, the total amount of glass produced in the immobilization of all OR sludge waste would be $\sim 830,000 \mathrm{~kg}$. This rough, initial calculation allows an estimate of the time required to vitrify all of the OR sludge, but this is dependent on the throughput of the selected melter. For a melter with a throughput of $100 \mathrm{Kg} / \mathrm{hr}$ (the design basis for the DWPF HLW melter), it would take 0.95 years of continuous operation to immobilize all of the waste. However, for a melter with a throughput of $10 \mathrm{Kg} / \mathrm{hr}$, it would require 9.5 years of continuous operation.

The scope of FY98 task involves a more detailed calculation which will include a range of times and waste loadings. In addition, the possibility of using different frits to increase the loading will be considered. The calculations of time and loadings will be necessary to determine the cost estimates for vitrification as the immobilization process for OR sludge.

\section{References}

1. R. D. Spence and T. M. Gilliam, Grout and Glass Performance in Support of Stabilization/Solidification of the MVST Tank Sludges, MVST Tank Sludge S/S, Rev. 0, September, 1996.

2. ASTM Procedure, C-1286-94, Determining Chemical Durability of Nuclear Waste Glasses: The Product Consistency Test (PCT).

3. C. M. Jantzen, N. E. Bibler, D. C. Beam, C. L. Crawford, and M. A. Pickett, Characterization of the Defense Waste Processing Facility (DWPF) Environmental assessment (EA) Glass Standard Reference Material (U), WSRC-TR-92-346, Rev. 1, June, 1993. 


\section{Peer Reviewed Publications Related to this Task}

M. K. Andrews and P. J. Workman, "Glass Formulation Development and Testing for the Vitrification of Oak Ridge Tank Waste," The Journal of the Franklin Institute, 1997.

J. R. Harbour and M. K. Andrews, "Waste Acceptance and Waste Loading for Vitrified Oak Ridge Tank Waste," The Journal of the Franklin Institute, 1997. (Appendix II).

\section{Attachments}

Appendix I - Statistically Designed Mixture Experiments

Appendix II - Waste Acceptance and Waste Loading for Vitrified Oak Ridge Tank Waste

\section{Distribution}

M. K. Andrews, 773-A

N. E. Bibler, 773-A

D. A. Crowley, 773-43A

T. B. Edwards, 773-42A

C. R. Goetzman, 773-A

J. R. Harbour, 773-43A

E. W. Holtzscheiter, 773-A

L. F. Landon, 704-1T

L. M. Papouchado, 773-A

C. T. Randall, 704-T

P. J. Workman, 773-A

STI, 703-43A (4 copies)

TFA, (7 copies) 


\section{APPENDIX I: STATISTICALLY DESIGNED MIXTURE EXPERIMENTS}

A phased-approach is being used to demonstrate the viability of vitrifying the Oak Ridge tank waste. An early step along this process was the successful vitrification of a surrogate for an "average" feed that was computed from the available information on the relevant sludge tanks. Several different compositions, five in fact, were shown to be viable frits for this task.

Next, a statistically designed experimental plan was developed to refine the frit formulation. The purpose of this phase of the study was the exploration of the relationships between product and process properties and glass composition to determine the critical component(s).

\section{DEFINING THE GLASS COMPOSITIONAL REGION}

The compositions of the successful frits consisted of mixtures of some or all of the following oxides: $\mathrm{Al}_{2} \mathrm{O}_{3}, \mathrm{CaO}, \mathrm{Fe}_{2} \mathrm{O}_{3}, \mathrm{~K}_{2} \mathrm{O}, \mathrm{Li}_{2} \mathrm{O}, \mathrm{Na}_{2} \mathrm{O}$, and $\mathrm{SiO}_{2}$. The glass composition region to be explored in this phase of the study was defined by holding the surrogate sludge feed constant and allowing the sludge feed loading to range from $33 \%$ to $55 \%$ of the glass composition for each of the frits of Table 7. To fully define the glass, the "Others" category was used to represent those components of the sludge feed not in the frit. Determining the high and low values for each oxide over all five frits led to Table 9 which defines the oxide ranges for this phase of the study.

\section{IDENTIFYING THE FEATURES OF A MIXTURE DESIGN}

Property models that relate process or product characteristics, such as liquidus temperature, to feed composition are inherently difficult due to the large number of constituents in the feed. Designing experiments to explore these relationships must overcome this problem of high dimensionality as well as one other complexity---the glass composition must be considered as a mixture.

The response of a mixture system depends only on the proportions of the constituents and not on the total amount of the mixture. This forces each of the design points to satisfy the following mathematical constraints:

$$
0 \leq x_{i} \leq 1 \quad \text { and } \quad \sum_{i=1}^{q} x_{i}=1
$$

where $x_{i}$ is the concentration of oxide $i$ (as a mass or weight fraction) in the mixture consisting of $q$ components [1].

The eight oxides presented in Table 9 are to be investigated as part of this study: $\mathrm{Al}_{2} \mathrm{O}_{3}$, $\mathrm{CaO}, \mathrm{Fe}_{2} \mathrm{O}_{3}, \mathrm{~K}_{2} \mathrm{O}, \mathrm{Li}_{2} \mathrm{O}, \mathrm{Na}_{2} \mathrm{O}, \mathrm{SiO}_{2}$, and Others. As described above, there are additional restrictions on the ranges of the concentrations of these oxides. These restrictions are expressed via ranges for each of the eight oxides of interest; these ranges have been provided in Table 9 . 
The mixtures of interest for this study must satisfy the following set of constraints

$$
0 \leq x_{i} \leq 1, \quad \sum_{i=1}^{q} x_{i}=1, \quad \text { and } \quad a_{i} \leq x_{i} \leq b_{i}
$$

where $x_{i}$ is the concentration of oxide $i$ (as a weight fraction) in the mixture consisting of $q(=8)$ components and the ranges, $a_{i}$ and $b_{i}$, for each oxide are the "Low Value" and "High Value" columns, respectively, of Table 9 [1].

The region of oxide concentrations that satisfy the constraints of (2) defines the candidate design space and forms a 7-dimensional region. The experimental design that is to be selected for studying the process and product properties for this project should consist of points within this region.

\section{STRATEGY FOR SELECTING DESIGN POINTS}

The geometric shape of the region bound by the constraints given by (2) is in general a hyperpolyhedron, and because the vertices of this region represent extreme conditions of the operating environment, they are often a good place to start in specifying the design points to be included in the experiment. As might be expected for this 7-dimensional hyperpolyhedron problem, the number of such extreme vertices is somewhat large. Help is available in the form of published algorithms that can be used to generate these vertices. These algorithms have been incorporated into several commercially available software programs that perform computer-aided design of experiments.

Two such programs were used as part of this phase of the study; they are SAS/QC ${ }^{\circledR}$ Software and JMP ${ }^{\circledR}$ both from SAS Institute, Inc. [2,3]. The JMP ${ }^{\circledR}$ software was used to generate a collection of 222 extreme vertices that bound the region defined by (2) using the ranges of Table 9 . This is usually a good place to start in looking for candidate design points. However, there are other compositions, in addition to these extreme vertices, that should be considered for inclusion in this design. It is usually desirable to consider points between the vertices as candidate design points. These points are called centroids, and a centroid is the average of points that share a constraint boundary [3]. Centroid points of various degrees can be generated and added as candidate design points. The overall centroid is determined by averaging all of the extreme vertices. The experimental design capabilities of JMP ${ }^{\circledR}$ were used to generate all of the centroids for the glass compositional region defined by Table 9 . The total number of glasses generated by $\mathrm{JMP}^{\circledR}$ is 3567 (including the 222 extremes). In addition, the ten compositions created by making glass using each of the 5 frits with the surrogate feed being loaded at $33 \%$ and $55 \%$ were added to this set of candidate glasses giving a total of 3577 candidate compositions. Obviously, there is a need to reduce the actual compositions tested to a (small) fraction of these candidate points.

\section{THE MODEL TO BE INVESTIGATED}

The glass properties of primary interest in this study are liquidus temperature and viscosity, also of interest is durability. Liquidus temperature defines a lower limit on melter temperature to avoid forming non-homogeneous glass, which directly affects 
processability and could potentially affect durability. Durability is important because it directly affects the reliable storage of the glass. Viscosity affects the ability to process the glass, imposing pouring and/or flow constraints.

The effort to reduce the number of candidate compositions revolves around the model that is to be investigated in this study. The primary model to be examined using the data resulting from the designed experiment being developed here is a linear (first-order) empirical model of the form

$$
y=\beta_{1} x_{1}+\beta_{2} x_{2}+\cdots+\beta_{8} x_{8}+\varepsilon
$$

where $y$ is a response of interest (such as liquidus temperature), $\beta_{i}$ is the unknown coefficient relating oxide $x_{i}(i=1,2, \ldots, 8)$ to $y, \varepsilon$ is an error term which is assumed to have a zero mean and constant variance.

\section{CRITERIA FOR SELECTING DESIGN}

Computer-aided design of experiments routines utilize one or more of the design optimality criteria that can be used to choose a set of points (the design) from a candidate list of points. Almost all of these computer-aided design routines are model dependent. Once a mixture model is chosen, such as the linear model given by (3), and a list of candidate design points is specified, such as the current 3577 compositions, a particular design (of a designated size) is selected from the candidate points that minimizes or maximizes a particular criterion. A final design may be selected from these designs of varying sizes using this same, and/or additional, criteria along with economic considerations.

Some of the more popular criteria that have been proposed for choosing a design are

a. A-optimality, which seeks to minimize the average variance of the estimates of the $\beta_{\mathrm{i}}$ 's.

b. D-optimality, which seeks to minimize the determinant of $\left(\mathbf{X}^{\prime} \mathbf{X}\right)^{-1}$ where each row of the matrix $\mathbf{X}$ is a design point, i.e., a composition given by $x_{1}, x_{2}, \ldots, x_{10}$.

c. G-optimality, which seeks to minimize the maximum prediction variance over a specified set of candidate design points.

These are model-dependent criteria, and a design that is optimal for one model form, for example a first-degree model such as (3), will not necessarily be optimal for another model such as a second-degree model [4]. However, since these criteria are varianceminimizing criteria, a design that is optimal for a given model using one of the above criteria is usually near-optimal for the same model with respect to the other criteria [4].

A feature of the JMP software package is its D-Optimal Design routine that uses criteria (b) to choose a set of points (the design) from a candidate list of points [3]. Values of the (a)-(c) criteria, denoted as A-efficiency, D-efficiency, and G-efficiency, respectively, are provided as part of the output from this routine. In addition, the correlations of the estimates of the $\beta_{i}$ 's for the optimal design are provided. 


\section{SOME ADDITIONAL COMMENTS REGARDING THE DESIGN}

The first-order model was used as the driver in selecting the design points. For this study, it is assumed that a linear function of these eight oxides will be adequate to model the properties of interest. But even when such a first-order model is of primary interest, there is a need to test this assumption. There is a need to ask the questions, "Does the linear model adequately fit the observed response values? Is there an indication of a lack of fit?" The overall centroid of the design was included as a design point so that it might be used as a check point for the fitted model. If there is nonlinear bending in the response of liquidus temperature over the hyperpolyhedron defined by (2), there should be some indication via a lack of fit for the response corresponding to this check point. Thus, it is important that centroids and other interior points be included in the design to serve as indicators for a lack of fit for the linear model.

Also, the batching of the glasses from this design was to take advantage of the available surrogate sludge. That is, for a given glass, the "Others" component could be used to determine the feed loading and all sludge components would then be added (in their relative proportions) to start the glass recipe. The recipe would then be completed by adding the appropriate amounts of the frit components. This approach led to some of the candidate design points becoming infeasible (they would involve a negative weight percent contribution from one or more of the frit oxides). Such points were removed from the 3577 candidate design points which left 897 glasses.

\section{THE EXPERIMENTAL DESIGN}

In this section, compositions are selected from the set of candidate compositions described in the previous section for inclusion in the experimental plan.

Using the JMP D-Optimal Design routine, a optimal design, for studying linear effects for the eight oxides, consisting of 16 compositions was determined from this list of 897 candidate design points. These 16 points chosen were selected as the best set of 16 points over 100 runs ("trips") of the D-Optimal Routine. One of these "optimal" glasses came from the set of 10 glasses determined by the extreme loadings using the original 5 frits. The overall centroid was also added to the design set. Thus, the final design for this phase of the study consisted of 17 glasses. The frit component for each of these glasses is given in Table 10.

\section{REFERENCES}

[1] Cornell, J. A., Experiments With Mixtures: Designs, Models, and the Analysis of Mixture Data, Second Edition, John Wiley \& Sons, Inc., New York, 1990.

[2] SAS Institute, Inc., SAS/QC Software: Reference, Version 6, First Edition, SAS Institute, Inc., Cary, NC, 1990.

[3] SAS Institute, Inc., JMP Statistics and Graphics Guide, Version 3, SAS Institute, Inc., Cary, NC, 1994.

[4] Snee, R. D., "Experimental Designs for Quadratic Models in Constrained Mixture Spaces," Technometrics, Volume 17, Number 2, May, 1975. 


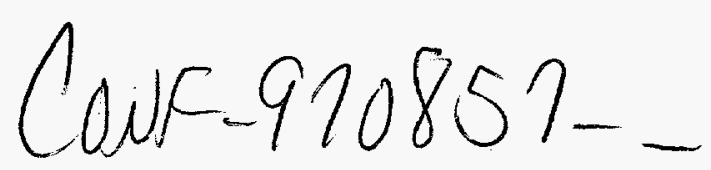

\title{
Appendix II:
}

\section{WASTE ACCEPTANCE AND WASTE LOADING FOR VITRIFIED OAK RIDGE TANK WASTE}

\author{
WSRC-MS-97-00042
}

John R. Harbour and Mary K. Andrews

Westinghouse Savannah River Company

Savannah River Technology Center

Aiken, SC 29808

A paper proposed for presentation and publication in the Proceedings of the Fourth Biennial Mixed Waste Symposium, Baltimore, MD, August 17-21, 1997

This report was prepared in connection with work done under Contract No. DE-AC09-89SR 18035 with the U.S. Department of Energy. By acceptance of this report, the publisher and/or recipient acknowledges the U.S. Government's right to retain a nonexclusive, royalty-free license in and to any copyright covering this report, along with the right to reproduce and to authorize others to reproduce all or part of the copyrighted report. 


\title{
Waste Acceptance and Waste Loading for Vitrified Oak Ridge Tank Waste
}

John R. Harbour and Mary K. Andrews

Savannah River Technology Center

Westinghouse Savannah River Company

Aiken, South Carolina, 29808

\begin{abstract}
The Office of Science and Technology of the DOE has funded a joint project between the Oak Ridge National Laboratory (ORNL) and the Savannah River Technology Center (SRTC) to evaluate vitrification and grouting for the immobilization of sludge from ORNL tank farms. The radioactive waste is from the Gunite and Associated Tanks (GAAT), the Melton Valley Storage Tanks (MVST), the Bethel Valley Evaporator Service Tanks (BVEST), and the Old Hydrofracture Tanks (OHF). Glass formulation development for sludge from these tanks is discussed in an accompanying article for this conference (Andrews and Workman). The sludges contain transuranic radionuclides at levels which will make the glass waste form (at reasonable waste loadings) TRU. Therefore, one of the objectives for this project was to ensure that the vitrified waste form could be disposed of at the Waste Isolation Pilot Plant (WIPP). In order to accomplish this, the waste form must meet the WIPP Waste Acceptance Criteria (WAC). An alternate pathway is to send the glass waste forms for disposal at the Nevada Test Site (NTS). A sludge waste loading in the feed of $-6 \mathrm{wt} \%$ will lead to a waste form which is non-TRU and could potentially be disposed of at NTS. The waste forms would then have to meet the requirements of the NTS WAC. This paper presents SRTC's efforts at demonstrating that the glass waste form produced as a result of vitrification of ORNL sludge will meet all the criteria of the WIPP WAC or NTS WAC.
\end{abstract}

\section{INTRODUCTION}

The waste in the Oak Ridge tanks contains both sludge and supernate (Bayne et al, 1996, Keller et al, 1997, and Francis and Herbes, 1997). This research focuses only on the sludge component of the waste. There are $-1,000,000 \mathrm{~kg}$ of wet sludge in these tanks containing roughly 50 wto water. The sludges from these tanks contain transuranic radionuclides at levels which will make the waste Transuranic (TRU) as the sludge loading in the glass is increased. In addition, the sludge contains RCRA metals at levels which could potentially make the waste form characteristically hazardous. One of the objectives for this project was to ensure that the vitrified waste form could be disposed of either at the Waste Isolation Pilot Plant (WIPP) or the Nevada Test Site (NTS). 
A major driver which affects the properties of the glass waste form is the waste loading. For this report the waste loading will be expressed as the amount of dry sludge present in the feed that will be delivered to the glass melter. The average weighted sludge composition from all four Oak Ridge Tank Farms contains 47.6 wto solids and 52.4 wto water. For example, 63 grams of wet sludge mixed with 70 grams of glass formers would produce a waste loading of 30 wto dry sludge in the melter feed. During vitrification, this feed will be converted to oxides in the melter to produce a waste oxide loading of 25 wto.

The chemical composition of the weighted average of all tanks within the four tank farms is provided in a separate report. The weighted average for the radionuclide composition is provided in the Tables of this paper. It is worth noting that the average composition is in reality not achievable. There is not a tank large enough in which to homogeneously blend the contents of every tank. Nevertheless, the average composition provides a starting point from which to develop a glass frit.

There is a large tank-to-tank variation in both chemical and radionuclide composition. There may also be significant intank variation in sludge composition both vertically and radially. All samples have been taken from a single riser port and therefore the degree of variation within the tanks has not been determined. The scope of this paper is limited to a fixed composition of the tank waste provided by the weighted average. Frits developed for this task will be evaluated for their capacity to adequately incorporate wastes within the envelope of chemical and radionuclide variations present in the tanks. This work will continue through next year.

It is important in the development of a glass formulation for tank waste, that the resultant glass waste form is acceptable for disposal. For this paper two disposal sites are discussed: the Nevada Test Site (NTS) near Las Vegas, Nevada and the Waste Isolation Pilot Plant (WIPP) in Carlsbad, New Mexico. The requirements for disposal at the NTS are detailed in the NTS waste Acceptance Criteria (WAC) (NTS WAC, 1996). The NTS will accept low-level radioactive waste if all of their requirements are met. The WIPP is not yet receiving waste but expects to receive shipments in 1998. To be accepted at WIPP, the waste must be transuranic (TRU). waste and the waste form must meet the WIPP WAC (1996). As will be demonstrated, acceptance at WIPP is dependent upon the waste loading in the glass.

TRU Components. In order to dispose of a waste form at the WIPP, it must be TRU waste. The WIPP WAC defines TRU waste 
as waste that contains alpha-emitting radionuclides with atomic numbers greater than that of Uranium (92) and which have a combined alpha activity level greater than $100 \mathrm{nCi} / \mathrm{g}$. Furthermore, the half life of the TRU radionuclides must be greater than 20 years to be included in the total alpha activity level. Calculations of the activity levels include only the mass of the waste form and can not include the mass of any containers.

The average Oak Ridge tank waste has a TRU level of 784 nCi/g. Table 1 lists the transuranic radionuclides and their associated alpha activity levels for the average waste. This sludge composition contains 52 wt\& water and 48 wto solids. Therefore, the TRU alpha activity for dry sludge is 1,647 $\mathrm{nCi} / \mathrm{g}$. Figure 1 presents the TRU alpha activity as a function of dry sludge (wt $q$ ) in the melter feed. This plot reveals that the waste becomes TRU at relatively low waste loadings $(\sim 6$ wto $)$.

TABLE 1. Transuranic radionuclides and associated alpha activities for the average Oak Ridge tank waste.

\begin{tabular}{|c|c|c|c|}
\hline & Curies/gram & nCi/g wet & nCi/g dry \\
\hline & & & \\
\hline $\mathrm{Am}-241$ & $2.3 \mathrm{E}-07$ & 228.3 & 479.6 \\
\hline $\mathrm{Cf}-252$ & $1.0 \mathrm{E}-09$ & 1.03 & 2.16 \\
\hline $\mathrm{Cm}-243$ & $2.8 \mathrm{E}-07$ & 279.2 & 586.5 \\
\hline $\mathrm{Np}-237$ & $2.2 \mathrm{E}-10$ & 0.22 & 0.45 \\
\hline $\mathrm{Pu}-238$ & $1.7 \mathrm{E}-07$ & 167.5 & 352.0 \\
\hline $\mathrm{Pu}-239$ & $8.2 \mathrm{E}-08$ & 81.9 & 172.2 \\
\hline $\mathrm{Pu}-240$ & $2.6 \mathrm{E}-08$ & 25.7 & 53.9 \\
\hline $\mathrm{Pu}-242$ & $5.4 \mathrm{E}-11$ & 0.05 & 0.11 \\
\hline $\mathrm{Pu}-244$ & 0 & 0 & 0 \\
\hline & $7.8 \mathrm{E}-07$ & 783.9 & 1646.9 \\
\hline
\end{tabular}


TRU LEVELS AS A FUNCTION OF DRY SLUDGE IN THE FEED

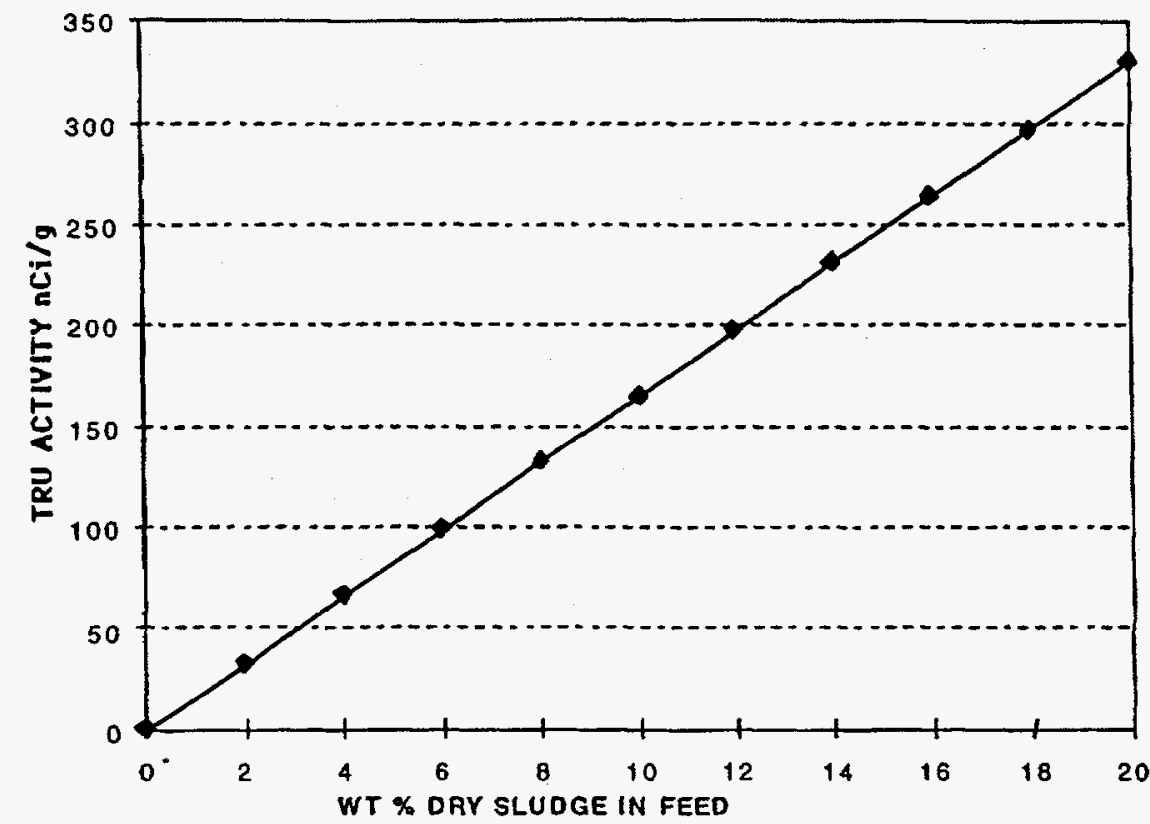

Series 1

FIGURE 1. TRU Alpha levels as a function of dry sludge loading in the feed.

For disposal of this vitrified waste at NTS, the dry sludge loading in the feed must be low enough that the glass produced contains less than $100 \mathrm{nCi} / \mathrm{g}$ of TRU alpha activity (and meets the NTS WAC). Therefore, Figure 1 partitions waste between NTS and WIPP at $100 \mathrm{nCi} / \mathrm{g}$. Since the composite waste is an average of all constituents over the four oak Ridge tank farms, there will be variation in TRU content with time in the vitrified waste form. Therefore, if WIPP is chosen as the disposal site, it is important that the feed has a higher waste loading to ensure that all of the glass is TRU to meet the requirements of the WIPP. Conversely for disposal of any of the waste at the NTS, a lower loading should be targeted to ensure that none of the waste is TRU.

\section{NTS DISPOSAL}

The possibility exists that the vitrified sludge could be shipped to NTS for disposal. For this to occur, the loading of dry sludge in the waste must be below 6 wt $\%$ on average to ensure that the waste is not TRU. The waste must also meet the requirements detailed in the NTS WAC.

The NTS does not accept mixed waste from outside the state of Nevada for disposal and the Oak Ridge sludge is not RCRA 
listed. As discussed below, glass waste forms have transformed and immobilized the sludge. Consequently, the glass waste form removes the concern over ignitable, corrosive and reactive waste. In addition, organics are destroyed due to the high temperatures involved in the vitrification process.

The one area of concern is RCRA regulatory limits for metals based on the EPA TCLP extract. If the metals in the glass are at concentrations less than the RCRA limits, there is no potential for the waste being characteristically hazardous. During the TCLP, a dilution of twenty times the original volume occurs. Therefore, the metals in the glass only need to be lower than twenty times the RCRA limits. Table 2 presents the RCRA metals and their projected concentrations in glass at 6 wto loading of dry sludge, along with the RCRA limits and twenty times the limits. The only metal which is greater than the 20 times limit is $\mathrm{Hg}$. However, mercury is a volatile element which is removed during the vitrification process and captured in the melter offgas system. Therefore, the waste form at low sludge loadings can not (on average) be characteristically hazardous. No credit is given here for the durability of the glass which certainly would reduce the amount of RCRA metals leached. This resistance to leaching could be used for cases where locally high concentrations of RCRA metals reside (e.g., an individual tank).

Table 2. RCRA metals in the sludge and glass at 6 wto loading.

\begin{tabular}{|c|c|c|c|c|c|}
\hline Metal & Wet sludge & Dry sludge & Glass at $6 \mathrm{wt} \%$ & Limit & $20 \times$ limit \\
\hline & $\mathrm{mg} / \mathrm{kg}$ & $\mathrm{mg} / \mathrm{kg}$ & $\mathrm{mg} / \mathrm{kg}$ & $\mathrm{mg}, \mathrm{L}$ & \\
\hline Silver & 7.9 & 16.6 & 0.99 & 5 & 100 \\
\hline Arsenic & 17.2 & 36.1 & 2.17 & 5 & 100 \\
\hline Barium & 93.7 & 196.7 & 11.80 & 100 & 2000 \\
\hline Cadmium & 9.2 & 19.3 & 1.16 & 1 & 20 \\
\hline Chromium & 337.4 & 708.8 & 42.53 & 5 & 100 \\
\hline Mercury & 65.6 & 137.8 & 8.27 & 0.2 & 4 \\
\hline Nickel & 63.4 & 133.2 & 7.99 & 50 & 1000 \\
\hline Lead & 462.2 & 971.1 & 58.27 & 5 & 100 \\
\hline
\end{tabular}

Although shipping the vitrified waste to NTS is possible if lower waste loadings are used, the required reduction in waste loading would result in a greater volume of waste. An analysis is underway to determine costs based on shipment and storage as a function of waste loading for both NTS and WIPP.

\section{WIPR DISPOSAL}

Calculations reveal that the vitrified waste form at $\sim 6$ wt 8 loading will produce a dose rate at the surface of a 55 gallon drum in excess of the $200 \mathrm{mrem} / \mathrm{hr}$ surface limit. 
Therefore, the waste forms sent to WIPP will be handled remotely. Remote Handled (RH) waste has requirements which are different than Contact-Handled (CH) waste. The WIPP WAC includes preliminary RH-TRU waste acceptance criteria, requirements, and compliance methods. However, the finalized requirements will not be available until the RH-TRU 72-B Cask SARP is approved. The following discussion is based on the preliminary $\mathrm{RH}$ requirements of the WIPP WAC.

Container: The container for RH-TRU waste is a stainless steel canister which can be no larger than 26 inches in diameter and 10 feet, 1 inch in length, and shall include a pintle for axial lifting. Glass can be poured directly into this canister or filled drums can be loaded into this canister.

Shipment to WIPP: The canister will fit into a RH-TRU 72-B Cask which will be transported by truck to WIPP. Each shipment can take one canister in one cask. It may be possible to include up to three 55 gallon drums into a single canister.

Weight of the RH TRU canister: The weight of the loaded canister must be less than 8,000 pounds. The density of glass $(-2.5 \mathrm{~kg} / \mathrm{L})$ is such that the 8,000 pound limit can not be reached, even for a completely filled canister.

Heat Generation: For remote handled TRU waste the thermal power requirement is a limit of 300 watts per canister. Calculations have been performed using the average radionuclide concentrations to calculate the wattage per gram of sludge. The result is $5.42 \mathrm{E}-07$ watt/gram (see Table 3 ). Assuming that each $\mathrm{RH}$ canister will be filled with $1700 \mathrm{Kg}$ of glass, there will be 0.58 watts/canister at melter feed containing 30 wto dry sludge. Wattage values could range from 0.12 watt at 6 wt\% loading to 0.97 watts at 50 wto dry sludge in the melter feed. Thus, the requirement of less than 300 watts/canister is readily met with this waste stream. 
Table 3. Thermal output from a canister filled with $1700 \mathrm{~kg}$ of glass at 30 wt? dry sludge in the feed.

\begin{tabular}{|c|c|c|c|c|c|c|}
\hline & watts/Ci & Bq/gram & Ci/gram & Ci/canister & watts/can & watts/g \\
\hline Co-60 & $1.54 \mathrm{E}-02$ & $3.35 E+04$ & $9.06 \mathrm{E}-07$ & $9.70 \mathrm{E}-01$ & $1.49 \mathrm{E}-02$ & $1.40 \mathrm{E}-08$ \\
\hline Sr-90 & $1.16 \mathrm{E}-03$ & $1.85 E+06$ & $5.00 \mathrm{E}-05$ & $5.36 \mathrm{E}+01$ & $6.21 \mathrm{E}-02$ & $5.80 \mathrm{E}-08$ \\
\hline$Y-90$ & $5.54 \mathrm{E}-03$ & $1.85 E+06$ & $5.00 E-05$ & $5.36 \mathrm{E}+01$ & 2.97E-01 & 2.77E-07 \\
\hline $2 r-93$ & $2.90 \mathrm{E}-04$ & $2.63 E+04$ & $7.11 \mathrm{E}-07$ & 7.60E-01 & $2.21 E-04$ & $2.06 \mathrm{E}-10$ \\
\hline$R u-106$ & $5.90 E-04$ & $1.83 E+04$ & $4.93 E-07$ & $5.30 \mathrm{E}-01$ & $3.12 E-04$ & $2.91 E-10$ \\
\hline Cs-134 & 1.02E-02 & $4.89 E+03$ & $1.32 \mathrm{E}-07$ & $1.40 \mathrm{E}-01$ & $1.45 \mathrm{E}-03$ & $1.35 E-09$ \\
\hline Cs-137 & $1.11 \mathrm{E}-03$ & $5.77 \mathrm{E}+05$ & $1.56 \mathrm{E}-05$ & $1.67 E+01$ & $1.85 \mathrm{E}-02$ & $1.73 \mathrm{E}-08$ \\
\hline$B a-137$ & $3.94 E-03$ & $5.77 E+05$ & $1.56 \mathrm{E}-05$ & $1.67 E+01$ & $6.58 \mathrm{E}-02$ & $6.15 E-08$ \\
\hline Eu-154 & $9.08 E-03$ & $6.97 E+04$ & $1.88 E-06$ & $2.02 E+00$ & 1.83E-02 & $1.71 \mathrm{E}-08$ \\
\hline Eu-155 & 7.59E-04 & $2.12 \mathrm{E}+04$ & $5.72 \mathrm{E}-07$ & $6.10 \mathrm{E}-01$ & $4.65 E-04$ & $4.34 \mathrm{E}-10$ \\
\hline$U-234$ & $2.83 E-02$ & $9.50 \mathrm{E}+02$ & 2.57E-08 & $3.00 E-02$ & $7.78 E-04$ & $7.27 E-10$ \\
\hline $\mathrm{U}-238$ & $2.49 \mathrm{E}-02$ & $9.44 E+02$ & $2.55 E-08$ & 3.00E-02 & $6.80 E-04$ & $6.35 \mathrm{E}-10$ \\
\hline $\mathrm{Pu}-238$ & $3.26 \mathrm{E}-02$ & $6.20 E+03$ & $1.68 \mathrm{E}-07$ & $1.80 \mathrm{E}-01$ & $5.85 \mathrm{E}-03$ & $5.46 \mathrm{E}-09$ \\
\hline $\mathrm{Pu}-239$ & $3.02 E-02$ & $3.03 E+03$ & 8.19E-08 & $9.00 \mathrm{E}-02$ & $2.65 E-03$ & $2.47 \mathrm{E} .09$ \\
\hline $\mathrm{Pu}-240$ & $3.06 \mathrm{E}-02$ & $9.50 E+02$ & $2.57 \mathrm{E}-08$ & $3.00 \mathrm{E}-02$ & $8.41 E-04$ & $7.86 \mathrm{E}-10$ \\
\hline $\mathrm{Pu}-241$ & $3.10 \mathrm{E}-05$ & $1.07 \mathrm{E}+04$ & $2.90 \mathrm{E}-07$ & $3.10 \mathrm{E}-01$ & $9.62 \mathrm{E}-06$ & $8.98 \mathrm{E}-12$ \\
\hline $\mathrm{Pu}-242$ & $2.90 \mathrm{E}-02$ & $2.00 \mathrm{E}+00$ & $5.41 \mathrm{E}-11$ & $5.79 \mathrm{E}-05$ & $1.68 E-06$ & $1.57 E-12$ \\
\hline Am-241 & $3.15 E-02$ & $8.45 E+03$ & $2.28 \mathrm{E}-07$ & $2.40 \mathrm{E}-01$ & $7.70 \mathrm{E}-03$ & $7.19 E-09$ \\
\hline Am-243 & $3.44 \mathrm{E}-02$ & $0.00 \mathrm{E}+00$ & $0.00 E+00$ & $0.00 \mathrm{E}+00$ & $0.00 \mathrm{E}+00$ & $0.00 \mathrm{E}+00$ \\
\hline $\mathrm{Ce}-144$ & $6.67 E-04$ & $3.64 E+04$ & $9.83 E-07$ & $1.05 E+00$ & $7.02 E-04$ & $6.56 E-10$ \\
\hline $\mathrm{Cm}-243$ & 3.67E-02 & $1.03 E+04$ & 2.79E-07 & $3.00 E-01$ & $1.10 \mathrm{E}-02$ & $1.02 E-08$ \\
\hline $\mathrm{Cm}-244$ & $3.50 \mathrm{E}-02$ & $3.64 E+04$ & $9.83 E-07$ & $1.06 \mathrm{E}+00$ & $3.68 \mathrm{E}-02$ & $3.44 \mathrm{E}-08$ \\
\hline Eu-152 & $7.60 \mathrm{E}-03$ & $1.32 E+05$ & $3.55 E-06$ & $3.81 E+00$ & $2.89 \mathrm{E}-02$ & $2.70 \mathrm{E}-08$ \\
\hline $\mathrm{Zr}-95$ & $5.00 E-03$ & $2.63 E+04$ & $7.11 \mathrm{E}-07$ & $7.60 \mathrm{E}-01$ & $3.81 \mathrm{E}-03$ & 3.55E-09 \\
\hline$U-233$ & $2.91 \mathrm{E}-02$ & $2.14 E+03$ & $5.77 \mathrm{E}-08$ & $6.00 \mathrm{E}-02$ & $1.80 \mathrm{E}-03$ & $1.68 E-09$ \\
\hline TOTAL & & & & & 5.81E-01 & $5.42 \mathrm{E}-07$ \\
\hline
\end{tabular}

Pu-239-FGE: For nuclear criticality concerns, the Pu-239 fissile gram equivalent (FGE) must be less than $325 \mathrm{~g}$ per canister. The value calculated from the composite data is $108 \mathrm{~g} /$ canister at $30 \mathrm{wt} \%$ dry sludge in the melter feed. These data are shown in Table 4. The major contributor to the Pu-239 FGE is U-235. These data show that even higher loadings of waste in the glass will not create a problem with this requirement. 
Table 4. Pu-239 Fissile Gram Equivalent for a glass made using 30 wto dry sludge from the Composite Composition.

\begin{tabular}{|c|c|c|c|c|c|c|c|}
\hline Isotope & PU-239 & Specific & Activity & Activity & Activity & FGE & FGE/canister \\
\hline & FGE & Activity Ci/g & Bq/g & Ci/g & 9 & g/g sludge & g \\
\hline $\mathrm{U}-233$ & $1.00 \mathrm{E}+00$ & $9.76 \mathrm{E}-03$ & 2137 & $5.78 \mathrm{E}-08$ & $5.92 \mathrm{E}-06$ & $5.92 \mathrm{E}-06$ & 6.337857 \\
\hline $\mathrm{U}-235$ & $1.00 \mathrm{E}+00$ & $2.19 \mathrm{E}-06$ & 7.6 & $2.05 \mathrm{E}-10$ & $9.38 \mathrm{E}-05$ & $9.38 \mathrm{E}-05$ & 100.4517 \\
\hline $\mathrm{Np}-237$ & $1.50 \mathrm{E}-02$ & $7.13 \mathrm{E}-04$ & 7.77 & $2.1 \mathrm{E}-10$ & $2.95 \mathrm{E}-07$ & $4.42 \mathrm{E}-09$ & 0.004732 \\
\hline $\mathrm{PU}-238$ & $1.13 \mathrm{E}-01$ & $1.73 \mathrm{E}+01$ & 6199 & $1.68 \mathrm{E}-07$ & $9.68 \mathrm{E}-09$ & $1.09 \mathrm{E}-09$ & 0.001172 \\
\hline $\mathrm{Pu}-239$ & $1.00 \mathrm{E}+00$ & $6.29 \mathrm{E}-02$ & 3032 & $8.19 \mathrm{E}-08$ & $1.3 \mathrm{E}-06$ & $1.3 \mathrm{E}-06$ & 1.395296 \\
\hline $\mathrm{Pu}-240$ & $2.25 \mathrm{E}-02$ & $2.30 \mathrm{E}-01$ & 950 & $2.57 \mathrm{E}-08$ & $1.12 \mathrm{E}-07$ & $2.51 \mathrm{E}-09$ & 0.00269 \\
\hline $\mathrm{Pu}-241$ & $2.25 \mathrm{E}+00$ & $1.04 \mathrm{E}+02$ & 10717 & $2.9 \mathrm{E}-07$ & $2.79 \mathrm{E}-09$ & $6.27 \mathrm{E}-09$ & 0.006711 \\
\hline $\mathrm{Pu}-242$ & $7.50 \mathrm{E}-03$ & $3.97 \mathrm{E}-03$ & 2.05 & $5.54 \mathrm{E}-11$ & $1.4 \mathrm{E}-08$ & $1.05 \mathrm{E}-10$ & 0.000112 \\
\hline Am-241 & $1.87 \mathrm{E}-02$ & $3.47 \mathrm{E}+00$ & 8446 & $2.28 \mathrm{E}-07$ & $6.58 \mathrm{E}-08$ & $1.23 \mathrm{E}-09$ & .0 .001318 \\
\hline $\mathrm{Cm}-243$ & $5.00 \mathrm{E}+00$ & $5.22 \mathrm{E}+01$ & 10330 & $2.79 \mathrm{E}-07$ & $5.35 \mathrm{E}-09$ & $2.67 \mathrm{E}-08$ & 0.028641 \\
\hline $\mathrm{Cm}-244$ & $9.00 \mathrm{E}-02$ & $8.18 \mathrm{E}+01$ & 36370 & $9.83 \mathrm{E}-07$ & $1.2 \mathrm{E}-08$ & $1.08 \mathrm{E}-09$ & 0.001158 \\
\hline TOTAL & & & & & & & 108.2314 \\
\hline
\end{tabular}

Pu-239 Equivalent Activity: The requirement for the $\mathrm{Pu}-$ 239 equivalent (PE) activity for RH TRU waste in the WIPP WAC is less than $1000 \mathrm{PE}-\mathrm{Ci} / \mathrm{canister.} \mathrm{This} \mathrm{requirement} \mathrm{is} \mathrm{based}$ on inhalation of $f$ ine particulates contaminated with radionuclides. It is interesting to note that the limit has been relaxed to $1800 \mathrm{PE} \mathrm{Ci}$ for a 55 gallon drum for contact handled TRU waste if the waste has been vitrified. This is due to the fact that the glass waste contains less fines and consequently, inhalation of particulate fines is not as great a concern. The preliminary requirements for the $\mathrm{RH}$ waste have not yet relaxed this requirement for vitrified waste. Nevertheless, the calculated PE activity for the composite waste has been calculated assuming a 30 wto loading of dry sludge in the melter feed. A value of $1.1 \mathrm{Ci}$ (PE) was obtained. This value demonstrates that this requirement can be readily met at reasonable waste loadings. The details of the calculations are shown in Table 5. 
Table 5. Pu-239 Equivalent Activity ( $\mathrm{PE}-\mathrm{Ci}$ ) for a glass made using 30 wto dry sludge in the feed

\begin{tabular}{|c|c|c|c|c|c|c|}
\hline Isotope & $\mathrm{Bq} / \mathrm{g}$ & $\mathrm{Ci} / \mathrm{gram}$ & $\mathrm{Ci} / \mathrm{kg}$ & $\mathrm{Ci} /$ can & weighting & $\mathrm{PE}-\mathrm{Ci}$ \\
\hline & & & & & factor & \\
\hline $\mathrm{U}-233$ & 2136 & $5.77 \mathrm{E}-08$ & $5.77 \mathrm{E}-05$ & 0.061829 & 3.9 & 0.015853 \\
\hline $\mathrm{Pu}-238$ & 6199 & $1.68 \mathrm{E}-07$ & 0.000168 & 0.179436 & 1.1 & 0.163124 \\
\hline $\mathrm{Pu}-239$ & 3032 & $8.19 \mathrm{E}-08$ & $8.19 \mathrm{E}-05$ & 0.087764 & 1 & 0.087764 \\
\hline $\mathrm{Pu}-240$ & 950 & $2.57 \mathrm{E}-08$ & $2.57 \mathrm{E}-05$ & 0.027499 & 1 & 0.027499 \\
\hline $\mathrm{Pu}-241$ & 10717 & $2.9 \mathrm{E}-07$ & 0.00029 & 0.310214 & 52 & 0.005966 \\
\hline $\mathrm{Pu}-242$ & 2 & $5.41 \mathrm{E}-11$ & $5.41 \mathrm{E}-08$ & $5.79 \mathrm{E}-05$ & 1.1 & $5.26 \mathrm{E}-05$ \\
\hline $\mathrm{Am}-241$ & 8446 & $2.28 \mathrm{E}-07$ & 0.000228 & 0.244477 & 1 & 0.244477 \\
\hline $\mathrm{Am}-243$ & 0 & 0 & 0 & 0 & 1 & 0 \\
\hline $\mathrm{Cm}-244$ & 36370 & $9.83 \mathrm{E}-07$ & 0.000983 & 1.052764 & 1.9 & 0.554086 \\
\hline $\mathrm{Cf}-252$ & 38 & $1.03 \mathrm{E}-09$ & $1.03 \mathrm{E}-06$ & 0.0011 & 3.9 & 0.000282 \\
\hline $\mathrm{Np}-237$ & 7 & $1.89 \mathrm{E}-10$ & $1.89 \mathrm{E}-07$ & 0.000203 & 1 & 0.000203 \\
\hline Total & & & & & & 1.099307 \\
\hline
\end{tabular}

Acceptable knowledge: Several of the requirements in the WIPP WAC can be addressed by acceptable knowledge. In this case the acceptable knowledge comes from the vitrification process. Glass formers are added to the sludge, and the mixture is fed to a melter which normally operates between $1100^{\circ} \mathrm{C}$ and $1400^{\circ} \mathrm{C}$. This high temperature and the relatively long residence time in the melter (the residence time depends on the size of the melter and throughput) provide assurance that the following requirements will be met:

1) Free 1iquids. The intent of the free liquids requirement is to limit liquid waste at the WIPP. The maximum amount of liquid per canister for RH-TRU is 6 liters. The process of vitrification removes all liquids from the feed such that the molten glass is poured into the canister at a temperature exceeding $1000^{\circ} \mathrm{C}$. The molten glass flows into the canister and solidifies as it cools. Proper administrative control then ensures that no additional water or other liquid can enter the canister.

2) Pyrophorics. The process of vitrification molecularly incorporates the radionuclides and other chemical elements within the glass. Pyrophorics are destroyed in the melter.

3) Mixed Waste. The WIPP WAC requires that RH-TRU waste can contain hazardous constituents only as cocontaminants with TRU waste. The glass formers which are added do not contain hazardous components. The WIPP WAC also requires that any corrosive, reactive, or ignitable characteristics shall be treated to remove the hazardous characteristic. The process of vitrification would remove 
any corrosive, reactive, or ignitable characteristic, if present, in the feed.

4) Explosives, Corrosives, and Compressed Gases. The WIPP WAC requires that there shall be no explosives, corrosives, or compressed gases. Vitrification removes these types of materials.

5) $P C B^{\prime}$ s. $\mathrm{PCB}^{\prime} \mathrm{s}$, if present in the feed, would be destroyed by the process of vitrification.

6) Flammable voc's. VoC's, if present, would be destroyed at the high melter temperatures. The glass waste form is non-volatile and consequently no additional volatile materials can be released to the canister headspace.

\section{CONCLUSIONS}

The development of a glass formulation for sludge immobilization leads to a waste form which is suitable for disposal at either the NTS or WIPP. The waste loading of the sludge determines the classification of the resultant glass waste form. Below a dry sludge feed loading of 6 wt $z$, the glass will be non-TRU and can be disposed of at the NTS. Above the 6 wto loading of sludge, the waste will be TRU and can be disposed of at the WIPP.

The process of vitrification provides acceptable knowledge for meeting a number of the WIPP WAC requirements. These include compliance with the requirements of free volume, explosives, RCRA metals, ignitables, corrosives, and PCB's.

The requirements of the WIPP WAC and the average composition of the Oak Ridge tank waste reveal that glass compositions that incorporate significant amounts of waste will be acceptable for disposal at WIPP. This provides more latitude in defining the optimum waste loading if vitrification is chosen as the method of immobilization of the waste. Efforts will continue to (1) determine the robustness of the glass formulation to incorporate variations in the chemical and radionuclide composition of the various tanks, and (2) compare costs of immobilization, storage, shipment, and eventual disposal at both WIPP and NTS based on waste loading in the glass.

\section{REFERENCES}

Bayne, C. K.; DePaoli, S. M.; DeVore, J. R.; Downing, D. J.; Keller, J. M. Statistical description of liquid low-level waste sytem transuranic wastes at ORNL. ORNL/TM-13351, 1996. 
Keller, J. M.; Giaquinto, J. M.; Meeks, A. M. Characterization of the MVST waste tanks located at ORNL. ORNL/TM-13357, 1997.

Francis, C. W.; Herbes, S. E. Summary review of the chemical characterization of liquid and sludge contained in the OHF at ORNL. ORNL/ER-395, 1997.

DOE Nevada Test Site Waste Acceptance Criteria, Rev. 0, 1996.

DOE Waste Acceptance Criteria for the Waste Isolation Pilot Plant, Rev. 5, 1996. 